\title{
El vínculo del personal estatutario de los servicios de salud y la competencia jurisdiccional
}

\author{
Juan Francisco Pérez Gálvez ${ }^{2}$ \\ Profesor Titular de Derecho Administrativo \\ de la Universidad de Almería
}

\begin{abstract}
SUMARIO : I. LA PRESTACIÓN DE SERVICIOS PROFESIONALES EN LOS CENTROS SANITARIOS. 1. Una actividad que ha preocupado a las sociedades de todos los tiempos. 2. Centros sanitarios privados. 3. Centros sanitarios públicos. 3.1. Personal funcionario. 3.2. Personal estatutario. 3.2.1. Estatuto Jurídico del Personal Médico. 3.2.2. Estatuto del Personal Sanitario no Facultativo. 3.2.3. Estatuto de Personal no Sanitario al Servicio de las Instituciones Sanitarias de la Seguridad Social. 3.2.4. M odificaciones. 3.3. Personal laboral. II. LEY 55/ 2003, DE 16 DE DICIEMBRE, DEL ESTATUTO MARCO DEL PERSO NAL ESTATUTARIO DE LOS SERVICIOS DE SALUD. 1. U na necesidad inaplazable. 2. El diseño aprobado -Estatuto Marco- queda pendiente de un posterior desarrollo autonómico. III. CONCEPTO DE PERSONAL ESTATUTARIO DEL SISTEMA NACIONAL DE SALUD. IV. NATURALEZA JURÍDICA DE LA RELACIÓN ESTATUTARIA. V. CLASIFICACIÓN DEL PERSO NAL ESTATUTARIO. 1. Situación anterior a la entrada en vigor del Estatuto Marco del Personal Estatutario de los Servicios de Salud. 1.1. Estatuto Jurídico del Personal Médico. 1.2. Estatuto Jurídico del Personal Sanitario no Facultativo. 1.2.1. Por su titulación y función. A. Por su titulación. B. Por su función. 1.2.2. Por la modalidad de prestación de servicios. A. De Zona. B. De Servicios de Urgencia. C. De Instituciones Sanitarias y Equipos Tocológicos. D. De Atención Primaria. 1.2.3. Por la vinculación a la Seguridad Social. 1.2.3. Por la vinculación a la Seguridad Social. 1.3. Estatuto Jurídico del Personal no Sanitario. 1.3.1. Grupo de personal técnico. 1.3.2. Grupo de servicios especiales. 1.3.3. Grupo de personal de oficio. 1.3.4. Grupo de personal subalterno. 1.4. La clasificación -a efectos retributivos- del Real Decreto-Ley 3/ 1987, de 11 de septiembre. 2. Situación actual. 2.1. En virtud del título exigido para el ingreso. 2.1.1. Ley de Ordenación de las Profesiones Sanitarias. A. Pro-
\end{abstract}

\footnotetext{
2 Abreviaturas utilizadas:

- BOCG: Boletín Oficial de las Cortes Generales.

- BOE: Boletín Oficial del Estado.

- CCO O: Comisiones Obreras.

- CEMS: Confederación Estatal de Médicos.
} 
fesiones sanitarias tituladas. B. Profesionales del área sanitaria de formación profesional. 2.1.2. Estatuto Marco del Personal Estatutario de los Servicios de Salud: personal de formación universitaria y personal de formación profesional. 2.2. En virtud de la función desarrollada. 2.2.1. Personal sanitario y personal de gestión y servicios. 2.2.2. El desarrollo profesional y su reconocimiento. 2.2.3. Puestos directivos. 2.3. En virtud del tipo de nombramiento. 2.3.1. Personal fijo. 2.3.2. Personal temporal: interino, eventual, sustituto. VI. EL VÍNCULO DEL PERSONAL ESTATUTARIO DE LOS SERVICIOS DE SALUD Y LA COMPETENCIA JURISDICCIONAL. 1. Justificación y utilidad de los antecedentes expuestos. 2. O rigen del estudio que abordo en este trabajo: dos sentencias del Juzgado ContenciosoAdministrativo núm. 7 de Madrid. 3. Ley O rgánica del Poder Judicial. 4. Ley de la Jurisdicción Contencioso-Administrativa. 5. Ley General de la Seguridad Social. 5.1. El artículo 45. 5.2. Excepción. 5.3. La derogación del art. 45 LGSS: una reforma que no llega a materializarse. A. Informe del Consejo General del Poder Judicial. B. El dictamen del Consejo de Estado. C. El debate en sede parlamentaria del Estatuto Marco del Personal Estatutario de los Servicios de Salud. VII. EL PRONUNCIAMIENTO DE LA JURISPRUDENCIA. 1. Resolución adoptada en casos similares. 2. Resolución adoptada por la Sala Especial de Conflictos de Competencia del Tribunal Supremo de España. VIII. FINAL.

\section{LA PRESTACIÓN DE SERVICIOS PROFESIONALES EN LOS CENTROS SANITARIOS 3}

\section{U na actividad que ha preocupado a las sociedades de todos los tiempos}

El ejercicio de las profesiones sanitarias es una actividad que ha preocupado a las sociedades de todos los tiempos.

- ET: Estatuto de los Trabajadores.

- FD: Fundamentos de Derecho.

- INSALUD: Instituto Nacional de la Salud.

- LGS: Ley 14/ 1986, de 25 de abril, General de Sanidad.

- LGSS: Ley General de la Seguridad Social.

- LJ: Ley 29/ 1998, de 13 de julio, Reguladora de la Jurisdicción Contencioso-Administrativa.

- LOPJ: Ley Orgánica del Poder Judicial de 1 de julio de 1985.

- LOPS: Ley 44/ 2003, de 21 de noviembre, de Ordenación de las Profesiones Sanitarias.

- LRJPA: Ley 30/ 1992, de 26 de noviembre, de Régimen Jurídico de las Administraciones Públicas y del Procedimiento Administrativo Común.

- OM: Orden Ministerial.

- PNV: Partido Nacionalista Vasco.

- REDA: Revista Española de Derecho Administrativo.

- RJ: Repertorio de Jurisprudencia.

- STS: Sentencia del Tribunal Supremo.

${ }^{3}$ En relación con los centros, servicios, establecimientos y actividades sanitarias Vide Juan FrancisCo PÉREZ GÁLVEZ, Creación y regulación de centros y establecimientos sanitarios, Bosch, Barcelona, 2003. 
La primera regulación de las profesiones sanitarias en España se produce mediado el siglo XIX, pues el 24 de julio de 1848 se aprueba el Reglamento para las Subdelegaciones de Sanidad interior del Reino ${ }^{4}$, cuyo art. 1 establece que para vigilar y reclamar el cumplimiento de las leyes, ordenanzas, decretos, reglamentos, instrucciones y órdenes superiores relativas a todos los ramos de Sanidad en que también está comprendido el ejercicio de las profesiones médicas, el de la farmacia, el de la veterinaria, la elaboración, introducción, venta y aplicación de las sustancias que puedan usarse como medicinas o ser consideradas como venenos, se establecerán en las provincias delegados especiales del Gobierno, que se titularán Subdelegados de Sanidad. En el art. 2 se precisa que en cada uno de los partidos judiciales aún de aquellas poblaciones en que haya más de uno, habrá tres Subdelegados de Sanidad ${ }^{5}$, de los cuales uno será profesor de Medicina o de Cirugía, otro de Farmacia y el tercero de Veterinaria.

\footnotetext{
4 Vide José de la PEÑ A, Legislación sanitaria vigente de medicina, Segunda edición, Tipografía y encuadernación de Senén Martín, Ávila, 1926.

${ }^{5}$ Entre las obligaciones de los Subdelegados de Medicina figuran las siguientes (tomadas de la Instrucción y Reglamento de las Subdelegaciones de 24 de julio de 1848):

I. Velar por el cumplimiento de lo dispuestos en las leyes, ordenanzas, reglamentos, decretos o reales órdenes vigentes sobre Sanidad.

II. Cuidar de que ninguna persona ejerza el todo o parte de la ciencia de curar sin el correspondiente título, y que los profesores se limiten al ejercicio de las facultades y al goce de los derechos que les conceda el que hubiesen obtenido.

III. Presentar a los Gobernadores, Alcaldes e Inspectores Provinciales de Sanidad cuantas reclamaciones creyeren necesarias por las faltas o contravenciones que notasen, tanto en el cumplimiento de las leyes o disposiciones gubernativas referentes al ejercicio de las profesiones médicas y demás ramos de sanidad, como en la observancia de los principios generales de higiene pública.

IV. Examinar los títulos de los profesores de la ciencia de curar que ejercieren o desearen ejercer su profesión en el distrito de la respectiva Subdelegación y horadar los sellos y firmas de los que fallezcan dentro de él.

V. Formar listas generales y nominales de los profesores que tengan su residencia habitual en el mismo distrito.

VI. Llevar los registros que sean necesarios para formar oportunamente y con exactitud las listas y notas de que trata el apartado anterior.

VII. Desempeñar las comisiones o encargos particulares que les confíen los Gobernadores, Inspectores provinciales o los Alcaldes, y evacuar los informes que les pidan dichas Autoridades.

VIII. La inspección y vigilancia sobre los Médicos y Cirujanos O culistas, Médicos dentistas, O dontólogos, Practicantes, Comadronas, Parteras y cuantos ejerzan en todo o parte la Medicina - la Cirugía en cuanto a su regular ejercicio.

IX. Examinar cuidadosamente el estado en que se encuentre en su respectivo distrito la propagación de la vacuna, procurando fomentarla.

$X$. Remitir dentro del mes de octubre, lista de los profesionales de la Medicina, al Gobernador civil, Director general de Sanidad, Inspector provincial y Subdelegado de Farmacia.
} 


\section{El Real Decreto de 27 de mayo de 1855 disponía:}

«Todos los profesores de Medicina y Cirugía, en sus diversos ramos, siempre que establezcan su residencia para el ejercicio de su facultad en cualquier punto de la Península, estarán obligados a la presentación de sus Títulos en la Subdelegación respectiva. Si ejercieren dos meses sin llenar este requisito, se les castigará con la multa de 40 reales por la primera vez, imponiéndoles doble castigo si reincidiesen en la falta.

Los Subdelegados llevarán un libro registro ${ }^{6}$ y pondrán en todos los títulos que reconozcan la toma de razón, el folio y número del registro en que haya sido inserta y la forma entera del Subdelegado. Teniendo que ser este registro en el Título original ${ }^{7}$.

Cuando ocurra el fallecimiento de un profesor de las indicadas clases, ya estuviese o no en el ejercicio de su facultad, se pondrá por la familia en conocimiento de la Subdelegación correspondiente, acompañando el título del fallecido. Si la familia desea conservar este documento, se devolverá a la misma después de inutilizado y hechas en el registro las correspondientes anotaciones.

Cuando algún profesor hubiere perdido su Título y solicita un duplicado, acudirá al Ministerio de Gracia y Justicia, por conducto del Gobernador de la provincia de su residencia, acompañando a su instancia una certificación del Subdelegado respectivo en que se manifieste estar matriculado el recurrente, y otra del Alcalde o Gobernador, asegurando que se le tiene por tal profesor y es de buena vida y costumbres. Si no

XI. Transmitir al Inspector provincial todas las noticias o reclamaciones que por su conducto hagan los Inspectores municipales.

XII. Revisar los títulos de los Médicos militares cuando ejerzan la Medicina en lo civil (R.O. 17 de abril de 1867).

XIII. Informar a los Inspectores provinciales de cuantas novedades ocurran en el distrito, relacionadas con la salud pública (R.D. 31 enero de 1919).

XIV. Prohibir el uso de aplicaciones eléctricas como agente curativo a todo el que no tenga título de Médico (R.O. 2 de enero de 1926).

XV. Impedir el ejercicio de la profesión de "Naturista" a quien la practique sin poseer el título Médico (R.O. 23 de marzo).

XVI. Impedir el ejercicio en España de las profesiones de Médico y O dontólogo transcurridos los seis años, fecha en que caducan las autorizaciones que a los extranjeros se conceden para el ejercicio de dichas profesiones de conformidad con lo establecido en los artículos 96 de la Ley de Instrucción pública y 3o del R.D. de 7 de noviembre de 1902 (R.0. 25 abril de 1921).

XVII. Perseguir el uso de la sacarina mezclada con sustancias alimenticias (R.O. 3 de abril de 1889).

XVIII. Instruir expediente de incapacidad cuando por algún Médico titular le sea denunciado este hecho respecto a practicante autorizado a asistir partos normales (R.D. 31 enero de 1902).

XIX. Vigilar constantemente los establecimientos de dementes (R.D. 19 mayo de 1885)».

${ }^{6}$ Q ue se ajustará al modelo determinado por la Real Orden de 14 de enero de 1916.

7 Vide Real Orden de 27 de abril de 1911. 
pudiera acreditarse el extravío por prueba documentada y no por información de testigos, la justificación se acompañará a la instancia».

Por la Ley de 28 de noviembre de 1855, sobre el Servicio General de Sanidad, se instituyeron los Jurados M édicos Provinciales de Calificación, que tenían por objeto prevenir, amonestar y calificar las faltas que cometieran los profesionales en el ejercicio de sus facultades, así como regularizar sus honorarios, reprimir los abusos y establecer una severa moral médica.

La Ley de 28 de noviembre de 1855, sobre el servicio general de sanidad, la Real Orden de 4 de enero de 1889 y la Instrucción General de Sanidad Pública aprobada por Real Decreto de 12 de enero de $1904^{8}$, se preocuparon de reglamentar, siquiera embrionariamente, el ejercicio profesional de lo que denominaron "el arte de curar" con el establecimiento de un registro de profesionales que pusieron a cargo de los Subdelegados de Sanidad. La entrada en vigor, ya a mediados del siglo XX, de otras leyes sanitarias, supuso el abandono del sistema de ordenación seguido hasta entonces. La Ley de Bases de la Sanidad Nacional, de 25 de noviembre de 1944, dedicó únicamente su Base 12

${ }^{8}$ En el Título III se regulaba la organización de las profesiones sanitarias libres, que tiene especial interés para este trabajo:

«Art. 62. Entendiéndose por Profesiones Sanitarias la Medicina y Cirugía, la Farmacia y la Veterinaria, el arte de los partos, el de practicante, el de dentista y, en general las complementarias que con título especial pudieran crearse en este ramo, todas estas profesiones serán objeto de la vigilancia de los Subdelegados en lo referente a la legitimidad de los títulos y a su regular ejercicio.

Art. 63. Todo Médico en ejercicio tiene el deber de enviar al Inspector municipal, al fin de cada mes, una relación de las enfermedades por él asistidas, consignando su diagnóstico y la terminación, cuando la hayan tenido, pudiendo omitir en ésta el nombre y las condiciones personales, en aquellos casos que su discreción lo juzgue necesario. [... ].

Art. 65. Todo Instituto de curación, médico, quirúrgico, de obstetricia, balneoterapia, etc, habrá necesariamente de estar dirigido por un Médico, y para su apertura serán necesarias visita previa del Inspector municipal y autorización de la Junta. Se exceptúan de este requisito los establecimientos de baños exclusivamente destinados a comodidad y aseo del público y los regidos por el Reglamento de baños y aguas minero-medicinales.

Art. 66. La Real Academia de Medicina redactará una lista de las sustancias medicamentosas, cuya venta ha de estar en absoluto prohibida fuera de las farmacias; otra lista de los específicos, con definición del concepto de estos últimos, y una tercera de las sustancias y materiales o preparados que por su doble empleo industrial y medicamentoso, y por su acción inofensiva, puedan expenderse fuera de las farmacias. [... ].

Art. 67. Nadie podrá ejercer una profesión sanitaria sin título que para ello le autorice con arreglo a las leyes del Reino. Para castigo, según el Código penal, de las transgresiones y abusos, cualquiera Inspector municipal, provincial o general a cuya noticia llegue, están ineludiblemente obligados a pasar el tanto de culpa a los Tribunales competentes por conducto de la Autoridad que corresponda. 
a la organización profesional de médicos, practicantes y odontólogos, con una única previsión, la de la existencia de Corporaciones Profesionales.

La Ley 14/ 1986, de 25 de abril, General de Sanidad, únicamente se refiere al ejercicio libre de las profesiones sanitarias, sin afrontar su regulación, aunque prevé, como competencia del Estado, la homologación de programas de formación postgraduada, perfeccionamiento y especialización de personal sanitario, así como la homologación general de los puestos de trabajo de los servicios sanitarios. Ello es así porque la Ley General de Sanidad es una norma de naturaleza predominantemente organizativa, cuyo objetivo primordial es establecer la estructura y funcionamiento del Sistema Sanitario Público en el nuevo modelo político y territorial del Estado que deriva de la Constitución de 1978.

Por todo ello, el ejercicio de las profesiones sanitarias, con alguna excepción como odontología, queda diferido a varias disposiciones, ya sean las reguladoras del sistema educativo, ya las de las relaciones con los pacientes, ya las relativas a los derechos y deberes de los profesionales en cuanto tales o ya las que regulan las relaciones de servicio con los centros, servicios y establecimientos públicos y privados. Esta situación, es la que trata de remediar, en parte, la Ley de Ordenación de las Profesiones Sanitarias?.

\section{Centros sanitarios privados.}

El régimen jurídico de la prestación de servicios profesionales por cuenta ajena en los centros sanitarios privados se determinará a través de los convenios colectivos aplicables al sector, que precisarán las condiciones por las que se rigen, estando sujetos a lo dispuesto en el Estatuto de los Trabajadores.

\section{Centros sanitarios públicos.}

En los centros sanitarios públicos podemos encontrar trabajadores sometidos a diversos regímenes jurídicos.

El que desee ejercer una de dichas profesiones, deberá registrar su título ante el Subdelegado correspondiente, habiendo de acreditar este requisito cuando ejerza su profesión fuera de la localidad respectiva.

Art. 68. La posesión de varios títulos da derecho al ejercicio de las respectivas profesiones. Para el ejercicio simultáneo de la M edicina, y la Farmacia será menester autorización de la Junta provincial en pleno».

${ }^{9}$ Vide Ley 44/ 2003, de 21 de noviembre, de O rdenación de las Profesiones Sanitarias, Preámbulo. 


\subsection{Personal funcionario.}

El artículo 85 de la LGS determina:

«1. Los funcionarios al servicio de las distintas Administraciones Públicas, a efectos del ejercicio de sus competencias sanitarias, se regirán por la Ley 30/ 1984, de 2 de agosto, y el resto de la legislación vigente en materia de funcionarios.

2. Igualmente, las Comunidades Autónomas, en el ejercicio de sus competencias, podrán dictar normas de desarrollo de la legislación básica del régimen estatutario de estos funcionarios».

El concepto de "funcionario" lo encontramos en el artículo 1으 de la Ley Articulada de Funcionarios Civiles del Estado, aprobada por Decreto 315/ 1964 de 7 de febrero:

«Los funcionarios de la Administración Pública son las personas incorporadas a la misma por una relación de servicios profesionales y retribuidos, regulada por el Derecho Administrativo».

Los funcionarios se integran en "Cuerpos", distinguiendo la misma Ley entre Cuerpos Generales y Cuerpos Especiales. Así lo precisa el art. 23 (Cuerpos Generales) :

«1. Corresponde a los funcionarios de los Cuerpos Generales el desempeño de las funciones comunes al ejercicio de la actividad administrativa, con excepción de las plazas reservadas expresamente a otras clases de funcionarios [ ... ].

2. Los Cuerpos Generales de Administración Civil son los siguientes: Técnico, de Gestión, Administrativo, Auxiliar y Subalterno».

y el art. 24 (Cuerpos Especiales):

«1. Son funcionarios de Cuerpos Especiales los que ejercen actividades que constituyen el objeto de una peculiar carrera o profesión y los que tienen asignado dicho carácter por razón de las circunstancias concurrentes en la función administrativa que les está encomendada.

2. La creación de nuevos Cuerpos Especiales deberá hacerse por Ley.

3. Los Cuerpos Especiales se rigen por sus disposiciones específicas y por las normas de esta Ley que se refieran a los mismos. En todo caso serán de aplicación general los preceptos contenidos en el presente título, con excepción de [...]».

Debo hacer una referencia a los Funcionarios de los Cuerpos Técnicos del Estado al servicio de la Sanidad Local, más conocidos como "funcionarios sanitarios locales", que, al ser Cuerpos Especiales se regían por sus disposicio- 
nes específicas, fundamentalmente por el Reglamento de Personal de los Servicios Sanitarios Locales, aprobado por el Decreto de 27 de noviembre de 1953. En él, encontramos los siguientes Cuerpos: M édicos Titulares; Farmacéuticos Titulares; Veterinarios Titulares; O dontólogos Titulares; Practicantes Titulares y M atronas Titulares.

Sin embargo hoy día la situación se ha modificado. Los odontólogos titulares no existen, y médicos, practicantes y matronas titulares se encuentran integrados en los Equipos Básicos de Atención Primaria, y aunque mantienen su status funcionarial, tanto en el aspecto funcional como en el retributivo, están homologados al resto del personal de los Equipos, es decir, al personal estatutario.

También debo señalar que una vez suprimidas las antiguas Entidades Gestoras y Servicios Comunes de la Seguridad Social por el Real DecretoLey 36/ 1978 e incorporados a la Ley 30/ 1984, muchos colectivos de personal que hasta entonces tenían la condición de estatutarios, vieron como sus correspondientes Estatutos fueron derogados por el Real Decreto 2664/ 1986, de 19 de diciembre, el cual procedió a la homologación del régimen del personal de la Seguridad Social con el de la Administración Civil del Estado y a ordenar los Cuerpos de funcionarios de la Administración de la Seguridad Social. Los Estatutos que se derogaban fueron los siguientes: 1978.

- Estatuto de Personal del I.N.P. aprobado por O.M. de 24 de abril de

- Estatuto de Personal del Mutualismo Laboral aprobado por O.M. de 30 de marzo de 1977.

- Estatuto de Personal del Servicio de Asistencia a Pensionistas aprobado por O.M. de 5 de abril de 1974.

- Estatuto de personal del Servicio de Reaseguros de Accidentes de Trabajo aprobado por O.M. de 14 de octubre de 1971.

- Estatuto de Personal de Recuperación y Rehabilitación de Minusválidos Físicos y Psíquicos aprobado por O.M. de 5 de abril de 1974.

- Estatuto de Personal del Instituto de Estudios de Sanidad y Seguridad Social aprobado por O.M. de 16 de octubre de 1978.

- Estatuto de Personal del Instituto Social de la Marina aprobados por O O.M M. de 22 de abril de 1971 y 30 de diciembre de 1978.

- Estatuto de Personal del Cuerpo de Intervención y Contabilidad de la Seguridad Social aprobado por O.M. de 31 de enero de 1979.

Por todo ello, una vez derogados estos Estatutos, los únicos que subsisten hasta la aprobación de la Ley 55/ 2003, de 16 de diciembre, del Estatuto Mar- 
co del Personal Estatutario de los Servicios de Salud, son los que fueron promulgados al amparo de la Ley General de la Seguridad Social, y son los tres que se refieren al personal de las Instituciones Sanitarias de la Seguridad Social.

\subsection{Personal estatutario.}

H asta la entrada en vigor del Estatuto Marco del Personal Estatutario de los Servicios de Salud el grupo normativo regulador del personal de los centros públicos estaba configurado por diversos estatutos jurídicos y las normas que los complementaban.

\subsubsection{Estatuto J urídico del Personal Médico.}

El Estatuto Jurídico del Personal Médico, fue aprobado por Decreto 3160/ 1966, de 23 de diciembre (BOE de 30 de diciembre, núm. 312), y obedecía al mandato del art. 116 de la Ley General de la Seguridad Social que dispone que el personal sanitario de la Seguridad Social prestará sus servicios conforme al Estatuto Jurídico que reglamentariamente se establezca. Su texto fue objeto de especial asesoramiento y colaboración por parte de la Comisión Especial sobre Asistencia Sanitaria de la Seguridad Social prevista en el apartado b) del artículo primero de la Orden de la Presidencia del Gobierno de 8 de junio de 1966.

En cuanto a su ámbito de aplicación, este Estatuto abarcaba al personal médico que en posesión del correspondiente nombramiento legal para sus puestos o plazas, presten sus servicios a la Seguridad Social. La actuación de estos facultativos comprendía las modal idades de medicina general, medicina de urgencia, así como las especialidades médicas y quirúrgicas establecidas en las normas sobre ordenación de la asistencia, si bien el Real Decreto 1033/ 1976 de 9 de abril, del Ministerio de Trabajo (BOE de 11 de mayo, núm. 113), en su disposición transitoria quinta, incluyó en este Estatuto al personal farmacéutico.

\subsubsection{Estatuto del Personal Sanitario no Facultativo.}

El Estatuto del Personal Sanitario no Facultativo, fue aprobado por Orden del Ministerio de trabajo de 26 de abril de 1973 (BB.0 O. E. de 28 y 30 de abril, núm. 102 y 103) y vino a refundir en un solo texto los Estatutos Jurídicos de las Enfermeras, de los Practicantes-Ayudantes Técnicos Sanitarios, y de las Matronas y Ayudantes Técnicos Sanitarios Femeninos en posesión del Diploma de Asistencia O bstétrica, promulgados con fechas 22 de abril y 16 de junio de 1967, así como las normas de carácter estatutario de las Auxiliares de 
Clínica de la Seguridad Social dictadas por el entonces Instituto Nacional de Previsión mediante Circular de régimen interior.

Su denominación inicial fue la de Estatuto del Personal Auxiliar Sanitario Titulado y Auxiliar de Clínica de la Seguridad Social, siendo posteriormente sustituida por la actual como consecuencia de la O rden de 26 de diciembre de 1986.

En cuanto a su ámbito de aplicación hay que decir que, según su artículo primero, este Estatuto regula la relación existente entre la respectiva Entidad Gestora y el personal auxiliar sanitario titulado y auxiliar de clínica derivada de la prestación de servicios a la Seguridad Social. Pero este artículo hay que completarlo con el artículo segundo que determina y precisa categorías concretas: diplomados en enfermería, ayudantes técnicos sanitarios, practicantes, matronas, enfermeras, fisioterapeutas, terapeutas ocupacionales, técnicos especialistas y auxiliares de enfermería.

\subsubsection{Estatuto de Personal no Sanitario al Servicio de las Instituciones Sa- nitarias de la Seguridad Social.}

Por O rden de 5 de julio de 1971, del Ministerio de Trabajo, se aprueba el Estatuto de Personal no Sanitario al Servicio de las Instituciones Sanitarias de la Seguridad Social (BOE de 22 de julio, núm. 174). Tal y como determina la propia O rden, fue aprobado por Orden ministerial de 28 de junio de 1968, el Reglamento de Personal de Servicios Especiales de Oficio y Subalterno de las Instituciones Sanitarias de la Seguridad Social, y resultaba aconsejable dictar una nueva regulación a fin de atemperar y poner al día las disposiciones contenidas en el mismo, procurando lograr así el mayor paralelismo posible con las normas contenidas en el Estatuto de Funcionarios del Instituto Nacional de Previsión. Por todo ello, el Ministerio de Trabajo, a propuesta de la Dirección General de la Seguridad Social aprueba el Estatuto de Personal no Sanitario al Servicio de las Instituciones Sanitarias de la Seguridad Social (art. 1) y deroga el régimen de personal de servicios especiales de oficio y subalterno de las Instituciones Sanitarias de la Seguridad Social aprobado por Orden de 28 de junio de 1968 ( art. $^{2}$ ) , que fue publicado en el BOE de 13 de julio. El Estatuto retrotraerá sus efectos al 1 de mayo de 1971 (art. 3o).

\subsubsection{Modificaciones.}

Estos Estatutos eran disposiciones normativas que regulaban el régimen jurídico del personal al servicio de las Instituciones Sanitarias de la Seguridad 
Social del Sistema Nacional de Salud, sea cual sea la Comunidad Autónoma en la que el personal prestara sus servicios. Debo recordar que hoy día se ha producido el traspaso de las funciones y servicios del INSALUD a todas las Comunidades Autónomas.

Estos Estatutos fueron objeto de diversas modificaciones, anteriores y posteriores a la Ley General de Sanidad. Con las mismas se pretendió adecuarlos a la realidad jurídica y social de cada momento, y la competencia era de la Administración del Estado, y no de las Comunidades Autónomas, aunque estas tuvieran transferidas las competencias en materia de Sanidad, y más concretamente, las funciones y servicios del Instituto $\mathrm{N}$ acional de la Salud. En este contexto debo recordar que el Real Decreto 1450/ 2000, de 28 de julio, dotó de una nueva estructura directiva al INSALUD, organismo adscrito al Ministerio de Sanidad y Consumo a través de la Secretaría General de Gestión y Cooperación Sanitaria, a quien correspondía la superior dirección de dicho organismo. Por su parte, el Real Decreto 840/ 2002, de 2 de agosto, por el que se modificó y desarrolló la estructura orgánica básica del Ministerio de Sanidad y Consumo, estableció que el Instituto Nacional de la Salud pasaba a denominarse Instituto Nacional de Gestión Sanitaria, conservando el régimen jurídico, económico, presupuestario y patrimonial y la misma personalidad jurídica y naturaleza de entidad gestora de la Seguridad Social. Le corresponde a la nueva entidad la gestión de los derechos y obligaciones del INSALUD, las prestaciones sanitarias en el ámbito de las ciudades de Ceuta y Melilla y realizar cuantas otras actividades sean necesarias para el normal funcionamiento de sus servicios, en el marco de lo dispuesto por la disposición transitoria tercera de la Ley 14/ 1986, de 25 de abril, General de Sanidad. Asimismo, se adscriben, al Instituto Nacional de Gestión Sanitaria la O rganización Nacional de Trasplantes y el Centro Nacional de Dosimetría de Valencia. EI Real Decreto 1087/ 2003, de 29 de agosto, derogó el citado Real Decreto 840/ 2002, de 2 de agosto, estableciendo una nueva estructura orgánica del Ministerio de Sanidad y Consumo, si bien mantuvo la denominación, características, funciones y organización que para el Instituto Nacional de Gestión Sanitaria se recogía en la norma derogada. Por Real Decreto 1746/ 2003, de 19 de diciembre, se regula la organización de los servicios periféricos del Instituto Nacional de Gestión Sanitaria y la composición de los órganos de participación en el control y vigilancia de la gestión.

Resultaría prolijo mencionar todas y cada una de las modificaciones operadas en estos Estatutos. Además, algunas de ellas ya no están vigentes al haber sido, a su vez, modificadas en todo o en parte, e incluso derogadas. En todo caso las más importantes son las siguientes: 
Estatuto Jurídico del Personal M édico:

- Real Decreto 1033/ 1976 de 9 de abril, del Ministerio de Trabajo que modificaba diversos aspectos relacionados con nombramientos y provisión de vacantes. H oy día no está vigente en su totalidad.

- Real Decreto 2166/ 1984 de 28 de noviembre, del Ministerio de Sanidad y Consumo (BOE de 6 de diciembre, núm. 292), que modificaba el sistema de provisión de plazas para el personal facultativo de los servicios jerarquizados de las Instituciones Sanitarias de la Seguridad Social.

Estatuto del Personal Sanitario no Facultativo:

- Orden de 14 de junio de 1984, que incorporó en la clasificación del personal la modalidad de "atención primaria".

- Orden de 11 de diciembre de 1984, del Ministerio de Sanidad y Consumo (BB.0O.E de 19 de junio y de 3 de julio, núms. 146 y 158, respectivamente), que introdujo la categoría de "técnico especialista".

- Orden de 26 de diciembre de 1986, del Ministerio de Sanidad y Consumo (BOE de 12 de enero de 1987, núm. 10), que introdujo la categoría de "auxiliar de enfermería" suprimiendo la de auxiliar de clínica y, además, modificó la denominación del propio Estatuto.

Estatuto del Personal no Sanitario:

- Las Ó rdenes de 28 de mayo, del Ministerio de Sanidad y Consumo (BOE de 30 de mayo, núm. 129) y 30 de junio de 1984, del Ministerio de Sanidad y Consumo (BOE de 8 de agosto, núm. 189), por las que se crearon los grupos de técnico, de gestión y administrativo dentro de la función administrativa.

Otras modificaciones comunes a los tres Estatutos y que han surgido como adelanto al Estatuto Marco y que han sido derogadas por éste, son las siguientes:

- El Real Decreto-Ley 3/ 1987, sobre sistema retributivo, asimilándolo al propio de los funcionarios públicos que se deriva de la Ley 30/ 1984, de 2 de agosto.

- El Real Decreto-Ley 1/ 1999, sobre selección de personal estatutario y provisión de plazas en las Instituciones Sanitarias de la Seguridad Social.

- La Ley 30/ 1999, sobre selección y provisión de plazas de personal estatutario de los Servicios de Salud, que mantiene transitoriamente la vigencia del Real Decreto-Ley anterior, aunque con rango reglamentario, hasta que se produzca su desarrollo en los distintos ámbitos de los respectivos Servicios de Salud.

\subsection{Personal laboral.}

Los centros asistenciales de los servicios de salud se nutren en principio de personal funcionario (sanitarios locales y funcionarios de los cuerpos creados por las Comunidades Autónomas) y, en mayor número, de personal esta- 
tutario. En principio, no tendría que existir personal fijo con vínculo laboral, 0 al menos así se desprendía del contenido de la LGS, arts. 84 (cuyos núms 1, 2 y 3 , han sido derogados por el Estatuto Marco del Personal Estatutario de los Servicios de Salud) y 85.

Sin embargo, determinadas circunstancias han hecho que exista algún personal con vínculo laboral fijo en estos centros asistenciales. A veces como consecuencia del traspaso de funciones, servicios y personal desde otras Administraciones Públicas, y en otros casos como consecuencia de sentencias judiciales, las cuales, además, han introducido la diferenciación entre los conceptos de "fijo" e "indefinido" en el vínculo laboral. Diferenciación recogida ya en el Real Decreto 2720/ 1998, de 18 de diciembre, por el que se desarrolla el artículo 15 del Estatuto de los Trabajadores en materia de contratos de duración determinada.

H asta la entrada en vigor del Estatuto Marco del Personal Estatutario de los Servicios de Salud, su régimen jurídico presentaba una gran falta de desarrollo pues su única referencia era el Estatuto de los Trabajadores, sin que existiese ninguna norma más particular (Convenio Colectivo) prevista para este personal. A partir de la publicación de la L ey 55/ 2003, de 16 de noviembre, su situación se modifica, pues también les será de aplicación, en todo aquello que no se oponga a su normativa específica y si así lo prevén los Convenios Colectivos aplicables al personal laboral de cada Comunidad Autónoma.

\section{LEY 55/ 2003, DE 16 DE DICIEMBRE, DEL ESTATUTO MARCO DEL PERSO NAL ESTATUTARIO DE LOS SERVICIOSDE SALUD}

\section{U na necesidad inaplazable.}

Esta apreciación que efectuo en el título del epígrafe -una necesidad inaplazable- se pone de manifiesto a lo largo de la tramitación parlamentaria de esta Ley (Grupo Federal de Izquierda U nida, señora Castro Fonseca) ${ }^{10}$ :

«[... ]. Ya poníamos de manifiesto entonces la urgencia de una regulación, señora ministra, para el personal estatutario, pendiente desde la promulgación de la Ley General de Sanidad, hace 17 años, que mantenía y sigue manteniendo a estos trabaja-

\footnotetext{
10 Vide Diario de Sesiones del Congreso de los Diputados de 11 de septiembre de 2003, núm. 275, sesión plenaria núm. 262, p. 107.
} 
dores y trabajadoras con una regulación, desde nuestro punto de vista, preconstitucional y a todas luces claramente insuficiente. Insuficiente no sólo por los cambios producidos en las relaciones laborales dentro del Sistema Nacional de Salud, sino también por la finalización del proceso transferencial que hace imprescindible el desarrollo de normas de carácter básico que contribuyan a la articulación del sistema y a darle cohesión. En este sentido, los profesionales sanitarios son el principal recurso y a su vez la principal fuente de gasto. Es impensable, por tanto, un sistema público cohesionado y coherente sin una regulación de personal que garantice unos mínimos y fije unas pautas comunes de actuación. Esto, entendemos en mi grupo parlamentario, lejos de entorpecer la gestión que corresponde a las capacidades constitucionales de las comunidades autónomas, debe favorecerla y permitir la permeabilidad entre los distintos servicios de salud $[\ldots]]^{11}$.

Por tanto, será esta disposición la que determinará todas las condiciones que afectan a este personal, pues ha derogado el régimen estatutario configurado por los tres Estatutos de Personal -todos ellos preconstitucionales- y las disposiciones que los modificaron, complementaron o desarrollaron. Este marco básico estará constituido por el propio Estatuto y por las disposiciones que, en el ámbito de cada Administración Pública, desarrollen tal marco básico y general.

Sin embargo, como norma sustantiva fundamental, nada precisa sobre la competencia jurisdiccional que habrá de resolver los litigios que afectan a este personal.

11 El Acuerdo Parlamentario para la Consolidación y Modernización del Sistema Nacional de Salud, aprobado por el Pleno del Congreso de los Diputados el día 18 de diciembre de 1997, determinó en su apartado 10 que se consideraba imprescindible el establecimiento de un nuevo modelo de relaciones laborales para el personal estatutario de los Servicios de Salud, a través de un Estatuto-Marco que habría de desempeñar un papel nuclear como elemento impulsor de la dinámica de evolución, desarrollo y consolidación de nuestro Sistema Nacional de Salud.

El propio Congreso de los Diputados señaló las líneas maestras de esa nueva regulación y marcó sus objetivos generales. Entre ellos cabe destacar los de incrementar la motivación de los profesionales y su compromiso con la gestión, el establecimiento de un adecuado sistema de incentivos, la desburocratización y flexibilización de las relaciones profesionales, la descentralización de los procesos de selección y de promoción profesional, la personalización de las condiciones de trabajo, especialmente en lo relativo a retribuciones y niveles de dedicación o la adecuación de las dotaciones de personal a las necesidades efectivas de los centros, a través de una normativa específica de carácter básico para este personal, con respeto tanto de las competencias para su desarrollo por las Comunidades Autónomas como del objetivo global de impulsar la autonomía de gestión de los Servicios, Centros e Instituciones. 


\section{El diseño aprobado -Estatuto Marco- queda pendiente de un posterior de- sarrollo autonómico.}

$\mathrm{H}$ a sido objeto de tratamiento parlamentario el desarrollo de la normativa básica contenida en esta Ley, alegando que con la actual redacción se obliga a las Comunidades Autónomas a aprobar Estatutos regional es que desarrollen el Estatuto Marco lo cual puede resultar improcedente, en tanto dicho desarrollo puede abordarse mediante normas legales o reglamentarias autonómicas sin tal caracterización, manteniendo su vigencia -total o parcial-aquellas disposiciones autonómicas anteriores a la entrada en vigor del Estatuto Marco por no oponerse a la regulación básica contenida en el mismo. Así lo expresa la enmienda núm. 93 del Grupo Parlamentario Coalición Canaria, publicada en el BOCG de 3 de julio de 2003, y justificada del siguiente modo:

«El término Estatuto se refiere a un cuerpo legal completo que habría de contemplar en su integridad todo el régimen del colectivo. Ello supondría tener que reproducir a nivel autonómico prácticamente la totalidad del texto del Estatuto Marco -puesto que en muchas materias la regulación es de tal detalle que no admite desarrollo por parte de las Comunidades Autónomas con la adición de la regulación autonómica de desarrollo que habría de abordarse de forma conjunta y simultánea a efectos de su incorporación a dicho texto, lo que contrasta con la previsión contenida en la disposición adicional sexta del proyecto de Ley que prevé la entrada en vigor y consecuente desarrollo autonómico de forma paulatina.

La otra alternativa menos rigurosa sería optar por un estatuto Autonómico que tan sólo contuviera las materias que se desarrollen en dicho ámbito y omitiera los aspectos ya contenidos en el Estatuto Marco, lo cual obligaría a proceder a su regulación simultánea, ya que en caso contrario se plantearía la duda de cuáles de tales normas debieran tener la consideración de "estatuto". A su vez ello supondría tener que manejar unas normas deslavazadas, lo cual dificulta su comprensión y aplicación, no tan sólo por los órganos gestores, sino por los tribunales de la Administración de Justicia.

Lo que exige el Estatuto marco, en tanto norma básica y detallista, es la regulación de determinadas cuestiones bien por ley (ej. régimen retributivo, infracciones y sanciones disciplinarias), bien por reglamento (ej. selección y provisión de plazas, procedimiento disciplinario) que se pueden producir de forma progresiva».

En todo caso, esta es una materia que será objeto de tratamiento por cada Comunidad Autónoma en virtud de lo establecido en la Disposición transitoria sexta de esta Ley:

«Disposición transitoria sexta. Aplicación paulatina de esta Ley. 
No obstante lo previsto en las Disposiciones Derogatoria Única12 y Final Segunda ${ }^{13}$, las previsiones de esta Ley que a continuación se indican producirán efectos en la forma que se señala:

a) Las previsiones de los artículos $40^{14}$ y $43^{15}$ de esta Ley entrarán en vigor, en cada Servicio de Salud, cuando así se establezca en las normas a que se refiere su artículo $3^{16}$. En tanto se produce tal entrada en vigor se mantendrán vigentes, en cada servicio de salud y sin carácter básico, las normas previstas en la Disposición Derogatoria Única.b), o las equivalentes de cada Comunidad Autónoma.

b) Se mantendrán vigentes, en tanto se procede a su regulación en cada servicio de salud, las disposiciones relativas a categorías profesionales del personal estatutario y a las funciones de las mismas contenidas en las normas previstas en la Disposición Derogatoria Única, e), f) y g).

c) Se mantendrá vigente, con rango reglamentario y sin carácter básico, y en tanto se proceda a su modificación en cada servicio de salud, la norma citada en la Disposición Derogatoria Única.d).

d) Las prestaciones de carácter social previstas en las disposiciones a que se refieren los apartados e) , f) y g) de la Disposición Derogatoria Ú nica, se mantendrán exclusivamente respecto a quienes ostenten derechos subjetivos ya adquiridos a tales prestaciones en el momento de entrada en vigor de esta Ley.

2. El límite máximo de ciento cincuenta horas anuales que se fija en el segundo párrafo del artículo $49.1^{17}$ de esta Ley, se aplicará de forma progresiva durante los diez años siguientes a su entrada en vigor, en la forma que determine el Gobierno mediante Real Decreto, adoptado previo informe de la Comisión de Recursos Humanos del Sistema Nacional de Salud. En dicho informe, que deberá ser elaborado en el plazo de 18 meses desde la entrada en vigor de esta norma, se analizarán detalladamente las implicaciones que en la organización funcional de los Centros Sanitarios, en la financia-

12 Vide Ley 55/ 2003, de 16 de diciembre, del Estatuto Marco del Personal Estatutario de los Servicios de Salud, Disposición Derogatoria Única: «Derogación de normas».

13 Vide Ley 55/ 2003, de 16 de diciembre, del Estatuto Marco del Personal Estatutario de los Servicios de Salud, Disposición Final Segunda: «Informes sobre financiación».

14 Vide Ley 55/ 2003, de 16 de diciembre, del Estatuto Marco del Personal Estatutario de los Servicios de Salud, art. 40: «Criterios generales de la carrera profesional».

15 Vide Ley 55/ 2003, de 16 de diciembre, del Estatuto Marco del Personal Estatutario de los Servicios de Salud, art. 43: «Retribuciones complementarias».

16 Vide Ley 55/ 2003, de 16 de diciembre, del Estatuto Marco del Personal Estatutario de los Servicios de Salud, art. 3: «N ormas sobre personal estatutario».

17 Vide Ley 55/ 2003, de 16 de diciembre, del Estatuto Marco del Personal Estatutario de los Servicios de Salud, art. 49: «Régimen de jornada especial». 
ción del Sistema $\mathrm{N}$ acional de Salud y en las necesidades de especialistas, tendrá la puesta en marcha de la indicada limitación, así como las posibles excepciones a la misma derivadas del hecho insular y las medidas que resulte conveniente adoptar en función de todo ello. I gualmente, en tal informe se analizarán las repercusiones económicas de una progresiva adaptación de la jornada de trabajo de los Centros y Servicios Sanitarios a la vigente con carácter general en el resto de los Servicios Públicos.

Para la elaboración del informe a que se refiere el párrafo anterior, la Comisión de Recursos H umanos del Sistema Nacional de Salud recabará las opiniones de expertos de las Administraciones Sanitarias, de los Servicios de Salud y de las O rganizaciones Sindicales».

También deberán tener en cuenta las Comunidades Autónomas lo dispuesto en la Disposición derogatoria única:

«Disposición derogatoria única. Derogación de normas.

1. Quedan derogadas, o se considerarán, en su caso, inaplicables al personal estatutario de los Servicios de Salud, cuantas disposiciones de igual o inferior rango se opongan o contradigan a lo dispuesto en la presente Ley y, especialmente, las siguientes:

a) Los números 1, 2 y 3 del artículo 84 de la Ley 14/ 1986, de 25 de abril, General de Sanidad.

b) El Real Decreto-Ley 3/ 1987, de 11 de septiembre, sobre retribuciones del personal estatutario del Instituto $\mathrm{Nacional}$ de la Salud y las disposiciones y acuerdos que lo complementan y desarrollan.

c) La Ley 30/ 1999, de 5 de octubre, de Selección y Provisión de Plazas de Personal Estatuario de los Servicios de Salud.

d) El Real Decreto-Ley 1/ 1999, de 8 de enero, sobre selección de personal estatutario y provisión de plazas en las Instituciones Sanitarias de la Seguridad Social.

e) El Estatuto Jurídico del Personal Médico de la Seguridad Social aprobado por Decreto 3160/ 1966, de 23 de diciembre, y las disposiciones que lo modifican, complementan y desarrollan.

f) El Estatuto de Personal Sanitario no Facultativo de las Instituciones Sanitarias de la Seguridad Social aprobado por Orden de 26 de abril de 1973, con excepción de su artículo 151, así como las disposiciones que lo modifican, complementan y desarrollan.

g) El Estatuto de Personal no Sanitario de las Instituciones Sanitarias de la Seguridad Social aprobado por Orden de 5 de julio de 1971, y las disposiciones que lo modifican, complementan y desarrollan.2. La entrada en vigor de esta L ey no supondrá la modificación o derogación de los Pactos y Acuerdos vigentes en aquellos aspectos que no se opongan o contradigan lo establecido en la misma».

Pues el Estado estaba habilitado competencialmente, tal y como se precisa en la Disposición final primera, para abordar este cometido:

«Disposición final primera. Habilitación competencial.

1. Las disposiciones de la presente Ley se dictan al amparo del artículo 149.1.18. a de la Constitución, por lo que las mismas constituyen bases del régimen estatutario del personal incluido en su ámbito de aplicación. 
2. La Disposición Adicional Segunda ${ }^{18}$ se dicta, además, al amparo del artículo 149.1.16. de la Constitución, por lo que sus previsiones constituyen bases de la sanidad.

3. Se exceptúan de lo establecido en el anterior número 1, la Disposición Adicional Segunda, en cuanto al personal con vínculo laboral de los Centros Sanitarios a los que la misma se refiere, y la Disposición Transitoria Primera ${ }^{19}$, que se dictan al amparo del artículo 149.1.7.. de la Constitución».

\section{CONCEPTO DE PERSONAL ESTATUTARIO DEL SISTEMA NACIONAL DE SALUD}

Tiene la condición de personal estatutario todo aquel que desempeña su función en los centros e instituciones sanitarias de los Servicios de Salud de las Comunidades Autónomas o en los centros y servicios sanitarios de la Administración General del Estado ${ }^{20}$ con esta naturaleza. Y efectúo esta apreciación, porque el Estatuto Marco del Personal Estatutario de los Servicios de Salud, será de aplicación al personal sanitario funcionario y al personal sanitario laboral que preste servicios en los centros e instituciones del Sistema Nacional de Salud gestionados directamente por entidades creadas por las distintas Comunidades Autónomas para acoger los medios y recursos humanos y materiales procedentes de los procesos de transferencias del Insalud, en todo aquello que no se oponga a su normativa específica de aplicación y si así lo prevén las disposiciones aplicables al personal funcionario o los Convenios Colectivos aplicables al personal laboral de cada Comunidad Autónoma.

18 Vide Ley 55/ 2003, de 16 de diciembre, del Estatuto Marco del Personal Estatutario de los Servicios de Salud, Disposición Adicional Segunda: «jornada y descansos de los centros del Sistema Nacional de Salud».

19 Vide Ley 55/ 2003, de 16 de diciembre, del Estatuto Marco del Personal Estatutario de los Servicios de Salud, Disposición T ransitoria Primera: «Aplicación paulatina de la jornada de trabajo al personal en formación mediante residencia».

${ }^{20}$ Así lo determina el Estatuto Marco del Personal Estatutario de los Servicios de Salud, art. 2.1. Además precisa: «2. En lo no previsto en esta Ley, en los normas a que se refiere el artículo siguiente, o en los Pactos o Acuerdos regulados en el Capítulo XIV, serán aplicables al personal estatutario las disposiciones y principios generales sobre función pública de la Administración correspondiente». 


\section{NATURALEZA JURÍDICA DE LA RELACIÓN ESTATUTARIA}

El art. 1 del Estatuto M arco del Personal Estatutario de los Servicios de Salud establece:

«Objeto.

La presente Ley tiene por objeto establecer las bases reguladoras de la relación funcionarial especial del personal estatutario de los Servicios de Salud que conforman el Sistema Nacional de Salud, a través del Estatuto-Marco de dicho personal».

Esta cuestión ha sido objeto de reiterados pronunciamientos jurisprudenciales.

El artículo 84 de la LGS (derogado por el Estatuto Marco del Personal Estatutario de los Servicios de Salud, en los apartados 1, 2 y 3), determina:

«1. El personal de la Seguridad Social regulado en el Estatuto Jurídico de Personal Médico de la Seguridad Social, en el Estatuto del Personal Sanitario Titulado y Auxiliar de Clínica de la Seguridad Social, en el Estatuto del Personal no Sanitario al Servicio de las Instituciones Sanitarias de la Seguridad Social, el personal de las Entidades Gestoras que asuman los servicios no transferibles y los que desempeñen su trabajo en los Servicios de Salud de las Comunidades Autónomas, se regirá por lo establecido en el Estatuto-Marco que aprobará el Gobierno en desarrollo de esta Ley, todo ello sin perjuicio de lo previsto en el artículo 87 de esta Ley.

2. Este Estatuto-Marco contendrá la normativa básica aplicable en materia de clasificación, selección, provisión de puestos de trabajo y situaciones, derechos, deberes, régimen disciplinario, incompatibilidades y sistema retributivo, garantizan do la estabilidad en el empleo y su categoría profesional. En desarrollo de dicha normativa básica, la concreción de las funciones de cada estamento de los señalados en el apartado anterior se establecerá en sus respectivos Estatutos, que se mantendrán como tales.

3. Las normas de las Comunidades Autónomas en materia de personal se ajustarán a lo previsto en dicho Estatuto-Marco. La selección de personal y su gestión y administración se hará por las Administraciones responsables de los servicios a que están adscritos los diferentes efectivos.

4. En las Comunidades Autónomas con lengua oficial propia, en el proceso de selección de personal y de provisión de puestos de trabajo de la Administración Sanitaria Pública, se tendrán en cuenta el conocimiento de ambas lenguas oficiales por parte del citado personal en los términos del artículo 19 de la Ley 30/ 1984».

El personal estatutario no está vinculado a los Servicios de Salud por una relación de naturaleza laboral, sino que su relación encierra una clara condición de Derecho público, al intervenir y contribuir a la realización de un servicio público. Así se desprende de lo que expresa el artículo 41 de la Constitución Española: 
«Los poderes públicos mantendrán un régimen público de Seguridad Social para todos los ciudadanos que garantice la asistencia y prestaciones sociales suficientes ante situaciones de necesidad, especialmente en caso de desempleo. La asistencia y prestaciones complementarias serán libres».

Es indiscutible la similitud y proximidad existente entre este personal estatutario de la Seguridad Social y el personal funcionario de las Administraciones públicas, si bien no puede olvidarse que aquél presente ciertas peculiaridades y caracteres específicos que le dan una estructura y consistencia propias, diferenciándolo de los funcionarios administrativos en sentido estricto. De ahí que, en no pocas ocasiones, se haya hablado de que este personal estatutario venía a constituir un "tertium genus" entre los trabajadores sometidos al Derecho laboral y los funcionarios que se rigen por el Derecho administrativo. Para avalar estas afirmaciones no hay mas que remitirse al art. 1.3.a) del Estatuto de los Trabajadores, o al artículo 1.5 de la Ley 30/ 1984, de 2 de agosto, reguladora de la función pública.

El régimen jurídico del personal que presta servicios en centros sanitarios públicos con respecto al que los presta en otras Instituciones Públicas o en otros centros, es tan patente, que ha justificado una regulación sustantiva e independiente de la funcionarial y laboral, e incluso se manifiesta en el ámbito jurisdiccional al que se atribuye el conocimiento de las controversias.

Sin embargo se predica la cualidad de funcionario público de estos trabajadores en el ámbito penal. Y esto es así porque el concepto penal de funcionario público incluye a todo el que por disposición inmediata de la ley o por elección o por nombramiento de autoridad competente participe en el ejercicio de funciones públicas. Y por tanto se trata de un concepto más amplio que el que se utiliza en otras ramas del ordenamiento jurídico y más concretamente en el ámbito del derecho administrativo. Mientras que para el Derecho administrativo los funcionarios son personas incorporadas a la Administración pública por una relación de servicios profesionales y retribuidos, regulada por el derecho administrativo, por el contrario, el concepto penal de funcionario no exige las notas de incorporación ni permanencia, sino la mera participación en la función pública. La definición legal de funcionario público recogida en el vigente Código Penal, se compone de dos elementos o requisitos ya que no es suficiente con que participe en el ejercicio de funciones públicas sino que se requiere, además, que se haya incorporado a dicho ejercicio por disposición inmediata de la ley o por elección o por nombramiento de autoridad competente, precisando que en el ámbito del derecho penal lo que importa es proteger penalmente el ejercicio de la función pública en or- 
den a sus propios fines, garantizando a un tiempo los intereses de la administración y los de los administrados. Y en torno a la función pública y al origen del nombramiento gira la definición penal de funcionario: lo es, el que participa del ejercicio de una función pública y por cualquiera de las tres vías de designación que recoge el precepto. Todo ello con independencia de los requisitos de selección para el ingreso, categoría, sistema de retribución, estatuto legal y reglamentario por el que se regule, sistema de previsión, estabilidad o temporalidad en el empleo, etc.

La colocación sistemática de las relaciones de servicios de régimen estatutario al lado de las relaciones de servicios de los funcionarios públicos es determinante a la hora de recurrir a la aplicación analógica de unas y otras normas en supuestos de laguna legal o carencia de regulación. La solución adoptada es la que manifiesta la Sentencia del Tribunal Superior de Justicia de La Rioja, núm. 346/ 2002, de 3 de diciembre (Sala de lo Social, Sección Única) [AS 2003|919]:

«[...]. Tales relaciones estatutarias poseen una configuración más próxima al modelo de la función pública, que al modelo de la contratación laboral; mayor afinidad que se aprecia tanto en el origen normal de la relación (concurso de méritos) , como en la fijación de su contenido (predeterminado por las normas de los estatutos particulares), como en la dinámica o desarrollo de la misma (donde se acentúan la estabilidad en el empleo y en el puesto de trabajo). La proximidad de las relaciones estatutarias al régimen de los funcionarios públicos, y el alejamiento correlativo del modelo laboral se han hecho más perceptibles en la evolución reciente del ordenamiento jurídico, como se puede comprobar en la exclusión expresa de la Ley de Relaciones Laborales y del artículo 1.3.a del Estatuto de Trabajadores, en Ia aplicabilidad a las mismas, si bien de forma subsidiaria, de las disposiciones de la Ley 30/ 1984 de Medidas Urgentes de Reforma de la Función Pública (art. 1.5), y en la propia inclusión del personal estatutario en la normativa de incompatibilidades del sector público, e incluso en la aplicabilidad de la Ley 70/ 1978 de 26 de diciembre, sobre reconocimiento de servicios previos a la Administración Pública, a dicho personal, regulada por el Real Decreto 1181/ 1989 de 29 de septiembre.

Esta colocación sistemática de las relaciones de servicios de régimen estatutario al lado de las relaciones de servicios de los funcionarios públicos es determinante a la hora de recurrir a la aplicación analógica de unas y otras normas en supuestos de laguna legal o carencia de regulación. Así lo ha declarado expresamente la Sala IV del Tribunal Supremo en sentencia de 22.1.1990 (RJ 1990 181) para la que los médicos de la Seguridad Social están sometidos a un régimen estatutario especial, no laboral, cuya regulación en función integradora del ordenamiento jurídico se ha de complementar, en situaciones de similitud, con la de los funcionarios a la que, dada su naturaleza administrativa, se aproxima (sentencia de 17.10.1991 [RJ 1991\7221]) » (F.D. 3). 
Y todo ello se justifica por las indudables afinidades y paralelismos, sobre todo en orden a la estructura normativa por la que se rigen, concepción y finalidad de la misma. Supuestos como el origen de la relación, la fijación de su contenido, dinámica o desarrollo de la misma (donde se acentúan la estabilidad en el empleo y en el puesto de trabajo) confirman esta consideración que acabo de exponer. Y sobre todo el alejamiento del modelo laboral se ha hecho más perceptible en la evolución del ordenamiento jurídico, y así continuará.

Todo lo expuesto se concreta en diversas sentencias. Entre otras cabe mencionar:

- Sentencia del Tribunal Supremo de 15 de julio de 1994 (Sala de lo So(ial). RJ 1994|6669:

«[... . 2) El personal estatutario de la Seguridad Social no está vinculado a ésta por una relación jurídica de naturaleza laboral, sino que su relación con ella encierra una clara condición de Derecho público, al intervenir y contribuir de alguna forma en la gestión, actuación y realización de un servicio público, como es la Seguridad Social, tal como se desprende de lo que expresa el artículo 41 de la Constitución Española. Es indiscutible la similitud y proximidad existente entre este personal estatutario de la Seguridad Social y e personal funcionario de las Administraciones públicas, si bien no puede olvidarse que aquél presente ciertas peculiaridades y caracteres específicos que le dan una estructura y consistencia propias, diferenciándolo de los funcionarios administrativos en sentido estricto. De ahí que, en no pocas ocasiones, se haya hablado de que este personal estatutario venía a constituir un «tertium genus» entre los trabajadores sometidos al Dere cho Laboral y los funcionarios que se rigen por el Derecho administrativo.

3) Y así el artículo 1.3.a) del Estatuto de los Trabajadores excluye explícitamente de su ámbito a este personal de la Seguridad Social. El contenido de esta norma pone de manifiesto la incuestionable proximidad o afinidad existentes entre este personal estatutario y los funcionarios públicos, pues no sólo separa a ambos del área de aplicación del Derecho laboral, sino que además los engloba y comprende en la misma exclusión. A lo que se añade lo que dispone el artículo 1.5 de la Ley 30/ 1984, de 2 agosto, según el que esta Ley, reguladora de la función pública, «tiene carácter supletorio para todo el personal al servicio del Estado y de las Administraciones públicas no incluido en su ámbito de aplicación», siendo claro que este precepto alcanza al personal estatutario de la Seguridad Social.

Por ello esta Sala ha venido resaltando, en los últimos años la aproximación existente entre la relación jurídica de este personal estatutario y la relación funcionarial administrativa [ Sentencias de 22 enero 1990 (RJ 1990। 181), 17 octubre 1991 (RJ 1991 I 7221) y 4 diciembre 1992 (RJ 1992\ 10421), entre otras] [F.D. 2]».

- Sentencia del Tribunal Supremo de 9 de noviembre de 1999 (Sala de lo Social). RJ 1999|9110: 
«Procede, ante todo, dilucidar si la relación existente entre el actor y la Conselleria de Sanidad y Consumo demandada -ahora recurrente- constituyó o no una verdadera relación laboral sujeta a la regulación del ET, cuyos arts. 49.2 y 55.3 se denunciaron como infringidos, y a este respecto es de tener en cuenta que la Sentencia de esta Sala de fecha 14 de octubre de 1996 (RJ 1996\ 7624) (recurso 389/ 1996), invocada en la recurrida, declaró en el supuesto de un médico que había sido nombrado con carácter interino al servicio de la Seguridad Social y sin que constara la suscripción de contrato de carácter laboral entre las partes, que la relación no era laboral sino estatutaria, y excluida por consiguiente del ámbito regulador del ET, conforme al art. $1.3 \mathrm{a}$ ) de éste, debiendo quedar, por el contrario, sujeta al Estatuto Jurídico del Personal Médico de la Seguridad Social.

Proyectando esta doctrina al caso que aquí se enjuicia, es de ver que entre las partes contendientes no existió contrato laboral alguno, antes bien: de la declaración de hechos probados de la Sentencia recurrida, complementada por la documentación aportada a los autos se evidencia que lo que se produjo fue un nombramiento en favor del actor como auxiliar de enfermería, con carácter interino, «de conformidad con lo dispuesto en el art. 13 del Estatuto del Personal Sanitario No Facultativo», lo que trae como consecuencia que sea este último Estatuto y no el de los Trabajadores el que deba regular la relación existente entre los litigantes. Esto sentado, resulta asimismo de aplicación el Real Decreto 118/ 1991, de 25 de enero sobre selección de personal estatutario y provisión de plazas en las Instituciones Sanitarias de la Seguridad Social (sustituido después por el Real Decreto-ley 1/ 1999 de 8 de enero, pero vigente en la fecha de los hechos enjuiciados), cuya disposición adicional cuarta establece en su párrafo primero la posibilidad de incorporar personal temporal cuando sea imprescindible por razones de servicio, señalando el párrafo segundo que «el personal así nombrado podrá mantenerse en la plaza hasta la incorporación a la misma de personal estatutario fijo designado para su desempeño, o hasta que la misma sea amortizada», precepto éste al que asimismo se ajustó el nombramiento y también el cese. Así pues, la Resolución recurrida siguió la recta doctrina al considerar que no existía relación laboral sino estatutaria, a diferencia de lo que sucede con la de contraste» (F.D. 2oํ).

Por ello se justifica una regulación sustantiva e independiente para este personal, tal y como determina la Sentencia del Tribunal Supremo de 9 de julio de 2001 (Sala de lo Social) [RJ 2001|7008]:

«[... ]. el régimen del personal del INSALUD que presta servicios en centros sanitarios con respecto al que los presta en otras Instituciones Públicas o en otros Centros, es tan patente, que ha justificado una regulación sustantiva e independiente de la funcionarial y laboral, e incluso en el ámbito jurisdiccional al que se atribuye el conocimiento de las controversias» (F.D. 4ㅇ).

Esta regulación, deberá adoptar forma de ley. Sirva como ejemplo la Sentencia del Tribunal Superior de Justicia de La Rioja, núm. 13/ 2003, de 28 de enero (Sala de lo Social, Sección Única). [JUR 2003|111600]: 
«[...]. Es cierto, como señalan las recurrentes, que reiteradamente ha declarado el Tribunal Supremo que la relación que vincula al personal sanitario de la Seguridad Social con la correspondiente Entidad Gestora, no es de naturaleza laboral, ni se rige por el Derecho del Trabajo, sino que tiene una clara naturaleza de Derecho Público y, aunque es diferente de la que une a los funcionarios públicos con la Administración, entre una y otra existen indudables afinidades y paralelismos, sobre todo en orden a la estructura normativa por la que se rigen, al tratarse ambas de relaciones estatutarias, siendo el vínculo que existe entre la Seguridad Social y el personal sanitario que le presta servicios, de naturaleza estatutaria, como claramente han venido proclamando los articulo 45 y 116 de la Ley General de Seguridad Social y como impone el articulo 84 de la Ley General de Sanidad de 25-4-1986, y más aún, cuando la doctrina del Tribunal Constitucional, como precisa el preámbulo del Real Decreto-Ley 3/ 1987, exige que el régimen estatutario de este personal se regule con norma con rango de Ley, como consecuencia de lo que preceptúa el articulo 103 de la Constitución Española (sentencia de 19-4-991 [RJ 1991\6238]) (F.D. 10) 》.

Queda claro que es imposible aplicar los preceptos del Estututo de los Trabajadores a este colectivo. Así lo pone de manifiesto la Sentencia del Tribunal Superior de Justicia de Cantabria 691/ 1996, de 17 de julio (Sala de lo Social) [AS 199612678]:

«El plazo prescriptivo es el de cinco años desde que el Tribunal Supremo en Sentencia de 29 septiembre 1994 (RJ 1994| 7265) así lo consideró y no, por lo tanto, el establecido en el artículo 59.2 del Estatuto de los Trabajadores. En aquella sentencia se expresaba cómo no es aplicable a la relación jurídico-estatutaria del personal sanitario de la Seguridad Social la normativa contenida en el Estatuto de los Trabajadores; en coherencia con ello, y con mayor sentido desde la vigencia de la Ley 30/ 1984, de 2 agosto, debe considerarse según esa resolución el plazo previsto en el artículo 54 del Texto Refundido de la Ley General de la Seguridad Social de 1974, actual artículo 43 del Texto Refundido de la Ley General de la Seguridad Social (RD Ley 1/ 1994, de 20 junio). Es un resultado más de la doctrina que reitera la Sentencia de 2 febrero 1995 (RJ 1995\ 772), la atinente a la imposibilidad de acudir a los preceptos del Estatuto de los Trabajadores, salvo casos verdaderamente excepcionales, a partir fundamentalmente de la Ley 30/ 1984, de 2 agosto (reforma de la función pública) de carácter supletorio (artículo 1.5) para todo el personal al servicio del Estado y de las Administraciones Públicas que implicó la aproximación de los regímenes del personal estatutario y de los funcionarios» (F.D. 1ㅇ).

\section{CLASIFICACIÓN DEL PERSONAL ESTATUTARIO}

Tal y como dispone el Estatuto Marco del Personal Estatutario de los Servicios de Salud, el personal estatutario se clasifica atendiendo a la función de- 
sarrollada, al nivel del título exigido para el ingreso y al tipo de su nombramiento ${ }^{21}$. A su vez se subdivide en: personal estatutario sanitario ${ }^{22}$ y personal estatutario de gestión y servicios ${ }^{23}$.

\section{Situación anterior a la entrada en vigor del Estatuto Marco del Personal Es- tatutario de los Servicios de Salud.} tatutos.

La clasificación del personal se determinaba en los correspondientes Es-

\subsection{Estatuto Jurídico del Personal Médico.}

Básicamente se establecía atendiendo a la clase de nombramiento. Para ocupar plaza en la Seguridad Social, el personal médico debía ostentar la nacionalidad española y estar en posesión del correspondiente nombramiento o autorización y en el pleno derecho de su capacidad de ejercicio profesional.

Por el carácter de su nombramiento, el personal médico podía tener la consideración de titular en propiedad, interino, eventual o contratado.

Eran considerados titulares en propiedad aquellos médicos a quienes se les adjudicaba con carácter definitivo una plaza, previo cumplimiento de los requisitos que se establecían en las disposiciones vigentes sobre la materia.

Tenía la consideración de interino el personal designado para desempeñar una plaza vacante, bien por corresponder a un facultativo, cuya situación le daba derecho a la reserva de dicha vacante, o bien porque la plaza no se había cubierto aun reglamentariamente, sin que en este último caso el facultativo que ocupaba interinamente la plaza pudiera permanecer en dicha situación más de nueve meses.

21 Vide Ley 55/ 2003, de 16 de diciembre, del Estatuto Marco del Personal Estatutario de los Servicios de Salud, art. 5.

22 Vide Ley 55/ 2003, de 16 de diciembre, del Estatuto Marco del Personal Estatutario de los Servicios de Salud, art. 6.

23 Vide Ley 55/ 2003, de 16 de diciembre, del Estatuto Marco del Personal Estatutario de los Servicios de Salud, art. 7. 
La interinidad no suponía derecho alguno a la plaza que se ocupaba, sea cual fuere el tiempo que durase dicha situación, y el nombramiento recaía sobre el facultativo que mejor puntuación tuviese en las Escalas de Médicos; a estos efectos y hasta su agotamiento definitivo, se daba preferencia a la Escala de mil novecientos cuarenta y seis. De no haber médicos pertenecientes a las Escalas, se debía solicitar a las bolsas de trabajo de los respectivos Colegios, la relación de los facultativos inscritos para, entre ellos, realizar la selección por concurso de méritos. Posteriormente, la gestión de las bolsas de trabajo fue traspasada a la Administración pública.

Se consideraba personal eventual el designado para atender situaciones extraordinarias, esporádicas o urgentes; el tiempo máximo que podría permanecer el facultativo en esta situación, era de seis meses.

En casos extraordinarios de alta especialización podían vincularse facultativos en régimen de contratación temporal a las instituciones sanitarias de la Seguridad Social. Su actuación se regía por lo previsto en cada contrato, sin que ello supusiera la creación de plazas de facultativos de la Seguridad Social, ni se adquiriese derecho alguno sobre las que pudieran crearse, cuya cobertura debía efectuarse de conformidad con las normas de provisión de vacantes establecidas en el propio Estatuto.

En aquellas localidades en que no existía cupo suficiente para la creación de una plaza de especialista, podría autorizarse excepcionalmente la actuación dentro de la Seguridad Social de especial istas que ejercían libremente como tales en dichas localidades, siempre que solicitasen expresamente tal autorización y la ordenación asistencial así lo aconsejase. Estas autorizaciones no suponían la creación de plazas ni el nombramiento de médico de la Seguridad Social.

El cese se producía por: renuncia; excedencia forzosa o voluntaria; jubilación; terminación del plazo para el que fue contratado; sanción disciplinaria de separación del servicio.

Como consecuencia de la entrada en vigor de la Ley 30/ 1999, de 5 de octubre, de selección y provisión de plazas de personal estatutario de los Servicios de Salud, las menciones del Estatuto a las distintas clases de personal temporal quedaron sustituidas por las que con carácter general regulaba esta Ley para todos los colectivos de personal estatutario, sea cual sea el Estatuto de aplicación.

\subsection{Estatuto Jurídico del Personal Sanitario no Facultativo.}

La clasificación se efectuaba en base a los siguientes criterios. 


\subsubsection{Por su titulación y función.}

Venían a ser muy similares.

\section{A. Por su titulación.}

Personal titulado de Grado Medio: Diplomado en Enfermería, Ayudantes Técnicos Sanitarios, Practicantes, Matronas, Enfermeras, Fisioterapeutas.

Otro personal titulado: Técnicos Especialistas (Formación Profesional de segundo grado), Auxiliares de Enfermería (Formación Profesional de primer grado) y Terapeutas ocupacionales.

\section{B. Por su función.}

La clasificación era la siguiente: Diplomados en Enfermería, Ayudantes Técnicos Sanitarios y Enfermeras; Practicantes-Ayudantes Técnicos Sanitarios; Matronas; Fisioterapeutas; Terapeutas ocupacionales; Técnicos especialistas; Auxiliares de Enfermería.

\subsubsection{Por la modalidad de prestación de servicios.}

\section{A. De Zona.}

Se considera personal auxiliar sanitario de zona a los practicantes-ayudantes técnicos sanitarios que prestan los servicios en régimen ambulatorio y domiciliario a las personas con derecho a la asistencia sanitaria de la Seguridad Social.

\section{B. De Servicios de U rgencia.}

Integra el personal auxiliar sanitario de los Servicios de U rgencia los practicantes-ayudantes técnicos sanitarios adscritos a dichos Servicios.

\section{De Instituciones Sanitarias y Equipos Tocológicos.}

Integran este personal:

- Los diplomados en enfermería, ayudantes técnicos sanitarios y enfermeras, matronas, fisioterapeutas, terapeutas ocupacionales, técnicos especialistas y auxiliares de enfermería que presten servicios en Instituciones Cerradas. 
- El mismo personal de Instituciones Abiertas.

- Las matronas que presten servicio en Instituciones Sanitarias y en Equipos Tocológicos.

\section{De Atención Primaria.}

Integra este personal los diplomados en enfermería o ayudantes técnicos sanitarios, enfermeras, practicantes-ayudantes técnicos sanitarios y auxiliares de enfermería adscritos a Equipos de Atención Primaria o a Servicios Jerarquizados de medicina general o pediatría-puericultura de Instituciones Abiertas.

\subsubsection{Por la vinculación a la Seguridad Social.}

Al igual que en el Estatuto Jurídico del Personal Médico se distinguía entre quien era titular en propiedad y quien era titular de nombramiento de carácter temporal.

Era considerado titular en propiedad, quien había obtenido nombramiento definitivo, conforme a los requisitos establecidos para la provisión de vacantes con tal carácter. En ningún caso podía transcurrir un plazo superior a seis meses desde la superación de las pruebas de acceso hasta el otorgamiento de nombramiento definitivo.

El personal nombrado para desempeñar una plaza vacante hasta que se provea en propiedad, era considerado personal interino.

El personal eventual era el designado, con carácter excepcional, para prestar una asistencia en orden a servicios o circunstancias especiales. El que realizaba su función como sustituto en plaza ocupada por su titular, propietario o interino, durante su ausencia por causa justificada también tenía esta consideración.

Los nombramientos o autorizaciones concedidos a personal interino o eventual, en cualquiera de sus modalidades, no daban derecho a los designados a quedar vinculados a la plaza que desempeñaban, más que con el carácter y tiempo que se consignaba de forma expresa en el nombramiento 0 autorización correspondiente.

Como he relatado con anterioridad, estos nombramientos de carácter temporal fueron sustituidos por los previstos en la Ley 30/ 1999, con idénticas consecuencias a las expuestas. 


\subsection{Estatuto Jurídico del Personal no Sanitario.}

La clasificación que establece es la siguiente.

\subsubsection{G rupo de personal técnico.}

Integrado por:

Personal técnico titulado. Los que con título de grado superior, medio o equivalente presten los trabajos para cuyo ejercicio les faculta dicho título. Se diversifica en tantas clases como títulos y funciones. El personal que aun poseyendo título no hubiera ingresado para la prestación de sus servicios como tal titulado, no queda comprendido en este grupo.

Personal no titulado. Los que sin estar en posesión de tales títulos tengan conocimientos técnicos debidamente acreditados mediante diploma o certificados de Escuelas Profesionales oficialmente reconocidas y hayan ingresado para realizar las funciones correspondientes. Se diversifica en tantas clases como funciones.

\subsubsection{G rupo de servicios especiales.}

Está formado por el personal que realice funciones que para su ejercicio necesite una especialización que le haya sido exigida para el ingreso. Son las gobernantas, telefonistas y el personal de función administrativa en sus distintos grupos ( técnico, de gestión, administrativo y auxiliar administrativo).

\subsubsection{G rupo de personal de oficio.}

Está integrado por todas las categorías que realicen funciones específicas en relación con los conocimientos propios de su actividad, los cuales les hayan sido exigidos para su ingreso. Son los mecánicos, electricistas, cal efactores, fontaneros, albañiles, carpinteros, jardineros, pintores, conductores, peluqueros, cocineros y costureras.

\subsubsection{G rupo de personal subalterno.}

Tienen a su cargo las funciones propias de su denominación, prestando la colaboración que le sea requerida en orden al debido cumplimiento de su misión. Está constituido por las siguientes Escalas:

Escala General. Está compuesta a su vez por las siguientes clases: jefes de personal subalterno; celadores. 
Escala de Servicio. Está compuesta a su vez por las siguientes clases: fogoneros; planchadoras; lavanderas; pinches; limpiadoras.

A esta clasificación que aparece en el Estatuto hay que añadir que a lo largo de los años han ido apareciendo nuevas categorías profesionales a las que las sucesivas $\mathrm{O}$ rdenes M inisteriales de Retribuciones (la última corresponde a 1986) iban dando carta de naturaleza y que por lo tanto han de ser consideradas también como categorías estatutarias.

Este Estatuto no consideraba más personal que el titular de plaza en propiedad, remitiendo a la contratación laboral de carácter temporal cuando era necesario incorporar personal no fijo a las Instituciones Sanitarias. No obstante, desde la Ley 30/ 1999, se incorpora también como estatutario el personal no sanitario vinculado de forma temporal, con los mismos efectos indicados con anterioridad.

\subsection{La clasificación -a efectos retributivos- del Real Decreto-Ley 3/ 1987, de 11 de septiembre.}

Se establece única y exclusivamente a efectos retributivos y se corresponde con la clasificación en grupo A, B, C, D y E, establecida para los funcionarios en virtud del título exigido para el ingreso en el mismo.

En su disposición adicional, determina las categorías que han de ser incluidas en cada uno de los grupos de clasificación, pudiéndose observar que, además de las mencionadas en los Estatutos aparecen:

- En el grupo "C": profesores de logofonía y logopedia; delineantes; jefes de taller y controladores de suministros.

- En el grupo “D”: fotógrafos; operadores de máquinas de imprimir; tapiceros; conductores de instalaciones; encargados de equipos de personal de oficios; auxiliares ortopédicos; monitores; locutores; azafatas de relaciones públicas.

- En el grupo "E": peones.

\section{Situación actual.}

Los criterios de clasificación del personal estatutario que establece el Estatuto Marco del Personal Estatutario de los Servicios de Salud, son los enunciados en el art. 5, que son objeto de análisis en cada uno de los epígrafes que desarrollo a continuación. 


\subsection{En virtud del título exigido para el ingreso.}

\subsubsection{Ley de 0 rdenación de las Profesiones Sanitarias ${ }^{24}$.}

Esta Ley regula los aspectos básicos de las profesiones sanitarias tituladas en lo que se refiere a su ejercicio por cuenta propia o ajena, a la estructura general de la formación de los profesionales, al desarrollo profesional de los mismos y a su participación en la planificación y ordenación de las profesiones sanitarias. Y sus disposiciones son aplicables tanto si la profesión se ejerce en los servicios sanitarios públicos como en el ámbito de la sanidad privada (art. 1).

\section{A. Profesiones sanitarias tituladas.}

El artículo 36 de la Constitución Española eleva a norma de rango constitucional, tanto el criterio de regulación legal de las profesiones tituladas, como el principio de régimen corporativo o colegial. Si en la norma constitucional se contiene la previsión básica sobre lo que sea la especificidad peculiar de las actividades profesionales, se traslada sin embargo al ámbito de la legislación ordinaria la regulación de los Colegios Profesionales y el régimen jurídico del ejercicio de las profesiones tituladas, sin que quede excluida la posibilidad legal del desarrollo pormenorizado vía reglamento de las leyes formales para determinar los temas básicos de la regulación de las profesiones así como las referentes al régimen jurídico aplicable a los Colegios Profesionales.

En el ámbito sanitario, la reserva de ley se refiere a una profesión, la de médico por ejemplo ( para lo que se necesita un título de Licenciado en Medicina y Ci-

\footnotetext{
24 Vide Ley 44/ 2003, de 21 de noviembre, de Ordenación de las Profesiones Sanitarias, Disposición transitoria tercera:

«Definición y estructuración de las profesiones sanitarias y de los profesionales del área sanitaria de Formación Profesional.

1. Los criterios de definición y estructuración de profesiones sanitarias y profesionales del área sanitaria de Formación Profesional que se contienen en los artículos 2 y 3 de esta Ley, se mantendrán en tanto se lleve a cabo la reforma o adaptación de las modalidades cíclicas a que se refiere el artículo 88 de la Ley O rgánica 6/ 2001, de 21 de diciembre, de U niversidades, para su adecuación al espacio europeo de enseñanza superior.

Una vez producida dicha reforma o adaptación, los criterios de definición de las profesiones sanitarias y de los profesionales del área sanitaria de la Formación Profesional y de su estructuración, serán modificados para adecuarlos a lo que se prevea en la misma.

2. El Gobierno procederá a la reordenación de las funciones de los distintos Departamentos de la Administración General del Estado en materia de formación sanitaria especializada cuando ello resulte aconsejable para adaptarla a lo que prevean las normas de las Comunidad Europea en relación con los requisitos de acceso a las actividades profesionales».
} 
rugía y una colegiación en una Corporación de Derecho Público), pero no se refiere a todas y cada una de las múltiples especialidades que "a posteriori" puedan alcanzar los titulados en Medicina y Cirugía para las que no se exige ninguna colegiación posterior, lo que resulta evidente en las disposiciones que regulan la obtención del título oficial de especialista. Por tanto, no ofrece duda, que estas disposiciones no regulan ninguna profesión titulada, sino una de las múltiples especialidades propias de los títulos universitarios cuya licenciatura es exigida. El título universitario es único, con independencia del puesto de trabajo que se ocupe.

A los efectos de la Ley de Ordenación de las Profesiones Sanitarias, son profesiones sanitarias, tituladas y reguladas, aquellas cuya formación pregraduada o especializada se dirige específica y fundamentalmente a dotar a losinteresados de los conocimientos, habilidades y actitudes propias de la atención de salud, y que están organizadas en Colegios Profesionales oficialmente reconocidos por los poderes públicos, de acuerdo con lo previsto en la normativa específicamente aplicable (art. 2.1 LOPS).

Las profesiones sanitarias que contempla se estructuran en los siguientes grupos (art. 2.2 LOPS):

a) De nivel Licenciado: Las profesiones para cuyo ejercicio habilitan los títulos de Licenciado en Medicina, en Farmacia, en Odontología y en Veterinaria, y los títulos oficiales de Especialista en Ciencias de la Salud para Licenciados a que se refiere el Título II de esta Ley ${ }^{25}$.

b) De nivel Diplomado: Las profesiones para cuyo ejercicio habilitan los títulos de Diplomado en Enfermería, en Fisioterapia, en Terapia Ocupacional, en Podología, en Ó ptica y O ptometría, en Logopedia y en Nutrición Humana y Dietética y los títulos oficiales de Especialista en Ciencias de la Salud para tales Diplomados ${ }^{26}$.

25 Vide Ley 44/ 2003, de 21 de noviembre, de Ordenación de las Profesiones Sanitarias, Título II: «De la formación de los profesionales sanitarios».

${ }^{26}$ Vide Ley 44/ 2003, de 21 de noviembre, de Ordenación de las Profesiones Sanitarias, Disposición adicional séptima:

«Carácter de profesionales sanitarios.

1. Lo establecido en esta Ley se entiende sin perjuicio del carácter de profesionales sanitarios que ostentan los Ayudantes Técnico Sanitarios y demás profesionales que, sin poseer el título académico a que se refiere el artículo 2, se encuentran habilitados, por norma legal o reglamentaria, para ejercer alguna de las profesiones previstas en dicho precepto.

2. Tendrán carácter de profesionales sanitarios los Licenciados en Ciencia y Tecnología de los Alimentos cuando tales titulados desarrollen su actividad profesional en Centros Sanitarios integrados en el Sistema Nacional de Salud o cuando desarrollen su ejercicio profesional, por cuenta propia o ajena en el sector sanitario privado». 
Cuando así resulte necesario, por las características de la actividad, para mejorar la eficacia de losservicios sanitarios o para adecuar la estructura preventiva 0 asistencial al progreso científico y tecnológico, se podrá declarar formalmente el carácter de profesión sanitaria, titulada y regulada, de una determinada actividad no prevista en el número anterior, mediante norma con rango de Ley (art. 2.3 LOPS) ${ }^{27}$.

\section{B. Profesionales del área sanitaria de formación profesional.}

Las directrices generales sobre los títulos de formación profesional y sus correspondientes enseñanzas mínimas, tienen por objeto establecer una estructura común de la ordenación académica de unas y otras. El objetivo de la nueva formación profesional se orienta, no sólo a la adquisición de conocimientos, sino sobre todo a la adquisición de la competencia profesional característica de cada título, que se expresará a través de su perfil profesional asociado, organizado en unidades de competencia, entendidas como un conjunto de capacidades profesionales ( referidas a las propiamente técnicas, a las de cooperación y relación con el entorno, a las de organización de las actividades de trabajo, a las de comprensión de los aspectos económicos y a las de adaptación a los cambios que se producen en el trabajo), que se expresan a través de una serie de acciones o realizaciones profesionales con valor y significado en el empleo, que se esperan de aquellos que obtengan el título profesional.

Los títulos profesionales son establecidos por el Gobierno, previa consulta a las Comunidades Autónomas, determinándose sus competencias profesionales características expresadas en términos de perfiles profesionales, necesarios para el desempeño cualificado de las profesiones correspondientes; los aspectos básicos del currículo de los ciclos formativos, que constituirán las enseñanzas mínimas y la duración de estos últimos.

La decisión constitucional de reservar a la ley en sentido estricto, a la ley formal emanada del poder legislativo, la regulación del ejercicio de las profesiones tituladas ( art. $36 \mathrm{CE}$ ), comporta, a la luz de reiterada doctrina constitucional, que debe ser ese producto normativo, sin que sean admisibles otras remisiones o habilitaciones a la potestad reglamentaria que las ceñidas a introducir un complemento de la regulación legal que sea indispensable por motivos técnicos o para optimizar el cumplimiento de las finalidades pro-

\footnotetext{
27 También se precisa en este mismo artículo: «Conforme a lo establecido en la Ley 10/ 1996, de 17 de marzo, sobre 0 dontólogos y otros profesionales relacionados con la salud dental, tienen carácter de profesión sanitaria la de Protésico Dental y la de H igienista Dental».
} 
puestas por la Constitución o por la propia Ley, el que regule: a) la existencia misma de una profesión titulada, es decir, de una profesión cuya posibilidad de ejercicio quede jurídicamente subordinada a la posesión de títulos concretos; b) los requisitos y títulos que la integran. Y todo ello porque el principio general de libertad que consagra la Constitución en sus artículos 1.1 y 10.1 autoriza a los ciudadanos a llevar a cabo todas aquellas actividades que la Ley no prohíba, o cuyo ejercicio no subordine a requisitos o condiciones determinadas. Porque el significado último del principio de reserva de ley, garantía esencial de nuestro Estado de Derecho, es el de asegurar que la regulación de los ámbitos de libertad que corresponden a los ciudadanos dependa exclusivamente de la voluntad de sus representantes, por lo que tales ámbitos han de quedar exentos de la acción del ejecutivo y, en consecuencia, de sus productos normativos propios, que son los reglamentos.

El efecto jurídico de la norma se limita por tanto a regular el derecho al título, que se adquiere por la superación de las específicas enseñanzas que se establecen y organizan, y a reconocer como inherente a él unas determinadas capacidades profesionales. No se regula el ejercicio de una profesión titulada, esto es, de un empleo, facultad u oficio que deja de ser libre por quedar su ejercicio subordinado a la posesión de un título, ni se penetra por tanto en el ámbito jurídico constitucionalmente reservado a la ley.

La normativa comunitaria europea, que trata de hacer efectiva la libre circulación de personas y servicios dentro de su ámbito espacial, suprimiendo los obstáculos que se puedan oponer a la facultad de ejercer una profesión, por cuenta propia o ajena, en un estado miembro distinto de aquel en que hayan adquirido su cualificación profesional, más que reglamentar una profesión, lo que pretende es el reconocimiento mutuo de ciclos de formación cursados con anterioridad a la entrada en la vida profesional, con el fin de lograr una recíproca equivalencia y poder determinar, de acuerdo con la formación adquirida en un país, cuál es la correspondencia que tiene en el resto de la Unión.

De conformidad con el artículo 35.1 de la Constitución, son profesionales del área sanitaria de formación profesional quienes ostentan los títulos de formación profesional de la Familia Profesional Sanidad, o los títulos o certificad os equivalentes a los mismos (art. 3.1 LOPS).

Los profesionales del área sanitaria de Formación Profesional se estructuran en los siguientes grupos ( art. 3.2 LOPS): 
a) De grado superior: Quienes ostentan los títulos de Técnico Superior en Anatomía Patológica y Citología, en Dietética, en Documentación Sanitaria, en Higiene Bucodental, en Imagen para el Diagnóstico, en Laboratorio de Diagnóstico Clínico, en O rtoprotésica, en Prótesis Dentales, en Radioterapia, en Salud Ambiental y en Audioprótesis.

b) De grado medio: Quienes ostentan los títulos de Técnico en Cuidados Auxiliares de Enfermería y en Farmacia.

Tendrán, asimismo, la consideración de profesionales del área sanitaria de Formación Profesional los que estén en posesión de los títulos de Formación Profesional que, en la familia Profesional Sanidad, establezca la Administración General del Estado conforme a lo previsto en el artículo 10.1 de la Ley O rgánica 5/ 2002, de 19 de junio, de las Cualificaciones y de la Formación Profesional $^{28}$ (art. 3.3 LOPS).

\subsubsection{Estatuto Marco del Personal Estatutario de los Servicios de Salud: personal de formación universitaria y personal de formación profesional.}

La clasificación que establece tanto para el personal estatutario sanitario (art. 6), como para el personal estatutario de gestión y servicios (art. 7), diferencia, atendiendo al nivel académico del título exigido para el ingreso, entre personal de formación universitaria (Licenciados y Diplomados) y personal de formación profesional (Técnicos superiores y Técnicos). También contempla para el personal estatutario de gestión y servicios una modalidad de clasificación que engloba bajo el apartado "Otro personal", aquellas categorías en las que se exige certificación acreditativa de los años cursados y de las calificaciones obtenidas en la Educación Secundaria O bligatoria, o título o certificado equivalente.

Por tanto, se reproduce el esquema contemplado en la Ley de Ordenación de las Profesiones Sanitarias, y además se hace todavía más patente, cuando entre Licenciados y Diplomados que configuran el personal estatutario sanitario, diferencia los que cuentan con el título de especialistas en Ciencias de la Salud o no.

28 Vide Ley Orgánica 5/ 2002, de 19 de junio, de Cualificaciones y de la Formación Profesional (BOE de 20 de junio, núm. 147), art. 10: «L as ofertas de formación profesional. 1. La Administración General del Estado, de conformidad con lo que se establece en el artículo 149.1.30a y 7a de la Constitución y previa consulta al Consejo General de la Formación Profesional, determinará los títulos y los certificados de profesionalidad, que constituirán las ofertas de formación profesional referidas al Catálogo Nacional de Cualificaciones Profesionales». 
Esta referencia obedece al contenido y configuración que establece la Ley de Ordenación de las Profesiones Sanitarias, Título II (De la formación de los profesionales sanitarios), Capítulo III (Formación especializada en Ciencias de la Salud) ${ }^{29}$.

\subsection{En virtud de la función desarrollada.}

\subsubsection{Personal sanitario y personal de gestión y servicios.}

La primera clasificación que se establece, es la que avalan los arts. 6 y 7 del Estatuto Marco del Personal Estatutario de los Servicios de Salud, distinguiendo entre aquellos que ostentan un nombramiento para el desarrollo de una profesión o especialidad sanitaria y aquellos que ostentan un nombra-

29 Vide Ley 44/ 2003, de 21 de noviembre, de Ordenación de las Profesiones Sanitarias, arts 15:

«Carácter y objeto de la formación especializada. 1. La formación especializada en Ciencias de la Salud es una formación reglada y de carácter oficial.

2. La formación especializada en Ciencias de la Salud tiene como objeto dotar a los profesionales de los conocimientos, técnicas, habilidades y actitudes propios de la correspondiente especialidad, de forma simultánea a la progresiva asunción por el interesado de la responsabilidad inherente al ejercicio autónomo de la misma»,

16: «T ítulos de Especialistas en Ciencias de la Salud. 1. Corresponde al Gobierno, a propuesta de los Ministerios de Educación, Cultura y Deporte y de Sanidad y Consumo, previo informe de la Comisión de Recursos Humanos del Sistema Nacional de Salud, del Consejo Nacional de Especialidades en Ciencias de la Salud y de la organización u organizaciones colegiadas que correspondan, el establecimiento de los títulos de Especialistas en Ciencias de la Salud, así como su supresión o cambio de denominación.

2. El título de Especialista tiene carácter oficial y validez en todo el territorio del Estado.

3. Sin perjuicio de las facultades que asisten a los profesionales sanitarios citados en los artículos 6.2 y 7.2 de esta Ley, ni de los derechos reconocidos, por norma legal o reglamentaria, a quienes se encuentran habilitados para desempeñar plaza de especialista sin el correspondiente título, la posesión del título de especialista será necesaria para utilizar de modo expreso la denominación de especialista, para ejercer la profesión con tal carácter y para ocupar puestos de trabajo con tal denominación en centros y establecimientos públicos y privados» y

17: «Expedición del título de Especialista. 1. Los títulos de especialista en Ciencias de la Salud serán expedidos por el Ministerio de Educación, Cultura y Deporte.

2. La obtención del título de especialista requiere:

a) Estar en posesión del título de Licenciado o Diplomado Universitario que, en cada caso, se exija.

b) Acceder al sistema de formación que corresponda, así como completar éste en su integridad de acuerdo con los programas de formación que se establezcan, sin perjuicio de lo establecido en el artículo 23 de esta Ley para el supuesto de nueva especialización.

c) Superar las evaluaciones que se determinen y depositar los derechos de expedición del correspondiente título». 
miento expedido para el desempeño de funciones de gestión o para el desarrollo de profesiones u oficios que no tengan carácter sanitario.

\subsubsection{EI desarrollo profesional y su reconocimiento.}

Una novedad que introduce la Ley de Ordenación de las Profesiones Sanitarias es el reconocimiento del desarrollo profesional, que puede habilitar para el desempeño de diferentes funciones en virtud del grado alcanzado 30 .

\subsubsection{Puestos directivos.}

La función que un profesional puede desarrollar dependerá de que ostente un puesto base, un puesto o cargo intermedio o un puesto directivo en el centro sanitario.

Sobre este último supuesto resulta de interés la Disposición adicional décima de la nueva Ley de O rdenación de las Profesiones Sanitarias:

«Las Administraciones Sanitarias establecerán los requisitos y los procedimientos para la selección, nombramiento o contratación del personal de dirección de los centros y establecimientos sanitarios dependientes de las mismas.

I gualmente las Administraciones Sanitarias establecerán los mecanismos de evaluación del desempeño de las funciones de dirección y de los resultados obtenidos, evaluación que se efectuará con carácter periódico y que podrá suponer, en su caso, la confirmación o remoción del interesado en tales funciones directivas».

En el BOCG de 3 de julio de 2003, núm. 151-5, se publicó la enmienda núm. 192, presentada por el Grupo Parlamentario Socialista, formulando una nueva disposición adicional con la siguiente redacción:

«Dirección de centros sanitarios.

1. Las Administraciones sanitarias establecerán los requisitos y los procedimientos para la selección, nombramiento o contratación del personal de dirección de los centros y establecimientos sanitarios dependientes 0 adscritos a las mismas.

Igualmente, las Administraciones sanitarias establecerán los mecanismos de evaluación del desempeño de las funciones de dirección y de los resultados obtenidos, evaluación que se efectuará con carácter periódico y que podrá suponer, en su caso, la confirmación o remoción del interesado en tales funciones directivas.

30 Vide Ley 44/ 2003, de 21 de noviembre, de O rdenación de las Profesiones Sanitarias, arts 37: «Normas generales», 38: «Desarrollo profesional» y 39: «H omologación del reconocimiento del desarrollo profesional». 
2. Corresponde a las Administraciones sanitarias la determinación de los puestos de dirección y gestión de los centros y establecimientos sanitarios dependientes 0 adscritos a las mismas, que tienen la consideración de puestos directivos a efectos de lo previsto en esta disposición.

Tales puestos podrán ser provistos en su caso, mediante contratos de trabajo incluidos en la relación laboral especial del personal de alta dirección».

Enmienda presentada por considerar que esta ley es el marco legal más adecuado para esta regulación. No fue aceptada.

\subsection{En virtud del tipo de nombramiento.}

Sobre esta modalidad de clasificación, el Estatuto Marco viene a reconocer como sus antecesores la condición de personal estatutario fijo y temporal.

\subsubsection{Personal fijo.}

En este contexto resulta necesario establecer la distinción entre la condición de trabajador fijo en la Administración Pública y la cualidad de relación de trabajo por tiempo indefinido que puede vincularse a la misma. El punto de partida es que el concepto de trabajador fijo no es exactamente coincidente con el de trabajador vinculado por una relación indefinida, en cuanto que puede adoptar modulaciones particulares en distintos sectores de actividad. Así ha ocurrido en el derecho histórico en las reglamentaciones y ordenanzas de trabajo del sector de la construcción o del sector agrícola. Y así ocurre en el derecho vigente a partir de la Ley 30/ 1984, en el sector de las Administraciones Públicas. A la luz de la doctrina jurisprudencial, la condición de trabajador fijo en las Administraciones Públicas se adquiere únicamente mediante la acreditación de mérito y capacidad en el correspondiente concurso público exigido por la normativa específica de dichas Administraciones, mientras que la calificación de una relación de trabajo como indefinida, con lo que ello comporta a los efectos del régimen jurídico de su duración y de su extinción, depende exclusivamente de lo establecido con carácter general en el Estatuto de los Trabajadores y en sus disposiciones complementarias.

\subsubsection{Personal temporal: interino, eventual, sustituto.}

Respecto del personal temporal, sigue otorgando carta de naturaleza a la diferenciación entre personal interino, de carácter eventual o de sustitución. Tanto el nombramiento como el cese se plantea en términos idénticos a los enunciados con anterioridad. 
Tal y como ha declarado reiterada jurisprudencia -Sentencia del Tribunal Superior de Justicia del País Vasco, núm. 1396/ 2002, de 4 de junio ( Sala de lo Social), AS 200212611-, la calificación como interino o eventual no pende del nombramiento por la entidad gestora, sino de la naturaleza de la plaza desempeñada:

«[... ]. Visto lo anterior, y aplicando a este supuesto la doctrina unificada del Tribunal Supremo contenida en la reciente sentencia de 4 de abril de 2001 (RJ 2001। 4128), en la que resolviendo un supuesto de cese de un médico interino erróneamente designado como eventual, señala que sólo es procedente si concurren las circunstancias que justifican la extinción de un vínculo estatutario de naturaleza interina, añadiendo que, en todo caso, la calificación como interino o eventual no pende del nombramiento por la entidad gestora sino de la naturaleza de la plaza desempeñada, hemos de concluir que el cese del nombramiento de sustitución de la actora por una de las causas determinantes del mismo (pérdida por la sustituida de su derecho a la reincorporación; art. 7.6 Ley 30/ 1999), pese al nombre de interinidad que se le haya dado al nombramiento, resulta ajustado a derecho. Por ello, previa estimación del recurso interpuesto, hemos de revocar la sentencia de instancia y desestimar la pretensión contenida en la demanda origen de las presentes actuaciones» (F.D. $2^{\circ}$ ).

Es admitido por la jurisprudencia que las Administraciones Públicas pueden utilizar la contratación temporal no sólo en los casos de sustitución de trabajadores con derecho a reserva de puesto de trabajo, sino también para la cobertura provisional de vacantes hasta que se cubran definitivamente las plazas por sus titulares a través de los procedimientos establecidos al efecto. El hecho de que se utilice el cauce de contrato para obra o servicio determinado, sólo implica una irregularidad formal, que no desvirtúa su naturaleza real de interinidad por vacante sin que pueda transformar un contrato temporal para la cobertura provisional de vacante en un contrato por tiempo indefinido. Sirva como ejemplo la Sentencia del Tribunal Superior de Justicia de Extremadura, núm. 69/ 2002, de 20 de febrero (Sala de lo Social), AS 2002/1048:

«[... ]. La cuestión entonces aparece nítida. La doctrina del Tribunal Supremo ni antes de la Ley 30/1999, ni después ha otorgado a la Administración una patente de corso para poder elegir a su antojo y conveniencia entre el nombramiento eventual y el de interinidad, antes denominado interinidad por vacante. Ello no es así tal y como se extrae de la propia sentencia invocada por la recurrente, siendo que en el caso estudiado el actor, tal y como se extrae del relato fáctico inalterado, fue nombrado con causa en la realización de servicios determinados de naturaleza temporal, coyuntural o extraordinaria «acumulo de tareas para el funcionamiento del plan $\mathrm{N}$ acional contra la droga», no obstante lo cual ha ocupado plaza en la Unidad de Medicina interna que se encontraba y se encuentra vacante, tal y como se deduce que haya sido contratado otro ATS para desempeñar dicha plaza, y no para resolver con carácter general una situa- 
ción de acumulo de tareas provocada por la vacancia de numerosos puestos de trabajo, lo cual no ha sido ni alegado ni probado. Es por ello por lo que se ha de convenir con el Magistrado de instancia que la demandada no ha respetado las normas sobre nombramiento de personal temporal y el negocio jurídico al que se denominó contrato eventual no es más que un contrato de interinidad para cubrir la vacante reseñada, contrato que se extingue por la incorporación de un titular o por la amortización de la plaza, causas que al no concurrir hacen nulo el cese del demandante, como más adelante se verá y no improcedente el despido. Este es precisamente el criterio mantenido por la recurrente en las Instrucciones, que también invoca, sobre vinculación temporal de personal estatutario en Instituciones Sanitarias del Insalud dictadas a propuesta de la Dirección General de Recursos H umanos de fecha 30 de noviembre de 1999, Instrucción Segunda, Dos, que establece que: «El carácter previsiblemente transitorio, esporádico o circunstancial de la actividad a acometer debe presidir cualquier nombramiento eventual. No debe utilizarse en actuaciones consolidables, sólo en situaciones de fuerza mayor, aumento coyuntural de demanda o extensión de un programa asistencial concreto que tenga una duración determinada o cobertura de la atención continuada». Y desde luego no puede calificarse como tal la situación descrita, en la que formalmente el actor fue nombrado para un programa concreto, no obstante lo cual se le destinó a la atención de un servicio distinto para atender una plaza de ATS en el Servicio de Medicina Interna que, a falta de otros hechos probados, está vacante, habiendo sido desempeñada por el actor desde el 28 de diciembre de 1999 hasta el 30 de junio de 2001, y desde el 1 de julio de 2001 ha sido nombrado ATS para el desempeño de dicha plaza.

Conforme a lo expuesto no puede convenirse con el recurrente en que se produzcan las denunciadas infracciones, sin que sea lícito invocar ahora listas de contratación ni puntuaciones cuando la actuación de la demandada ha sido la que ha provocado la aplicación de la normativa expuesta, sin olvidar que el actor ha estado vinculado con aquélla un año y seis meses, si bien mediante sucesivos contratos que esconden una situación no coyuntural sino prolongada en el tiempo y a la que no se puede atender con tal clase de nombramientos, que lo único que facilitan es el poder cesar a los contratados a conveniencia de la demandada, lo cual no es conforme a la normativa citada y hace ilícito el término fijado para su vencimiento» (F.D. 4ㅇ).

Sin embargo debo destacar que la doctrina del Tribunal Supremo no otorga a la Administración una patente de corso para poder elegir a su antojo y conveniencia entre el nombramiento eventual y el de interinidad. Así lo determina laSentencia del Tribunal Supremo de 9 de julio de 2001 (Sala de lo Social), RJ 2001\7010:

«[...]. b) Según doctrina reiterada de esta Sala, la celebración de un contrato eventual, al que se le asigna como causa la falta de personal, precisamente en un Hospital público, aunque no de la Seguridad Social, no es algo carente de consecuencias, en el sentido de constituir una mera falta subsanable o irrelevante; hay que entender, por el contrario, que no ha existido un error de calificación en el contrato, sino un uso 
desviado de la forma de contratación, porque en (esos) contratos eventuales no se identifica ninguna plaza vacante que pueda desempeñarse en interinidad hasta su cobertura, sino genéricamente una situación de falta de personal que, aparte su difícil encaje en el art. 15.1.b/ del Estatuto de los Trabajadores, nunca podría autorizar una relación que ha excedido con mucho la duración límite autorizada para los contratos de eventualidad (cfr. de esta Sala, de 26 octubre 1999 [ RJ 1999\ 7497], y las que en ella se cita).

c) En nuestro caso no se celebró exclusivamente contratos por una supuesta necesidad eventual de acumulación de tareas, sino que luego se utilizó la figura del contrato de interinidad por vacante. Esto no impide una consideración global de la situación, es decir, de todos los contratos celebrados, para decretar la irregularidad originaria del vínculo laboral de los actores, que transciende luego y se perpetúa, aunque se formalice otro tipo de relación. Así se desprende con claridad de nuestra sentencia de 20 febrero 1997 ( RJ 1997 1457), donde se advierte que en situaciones parecidas, todos los contratos pasan a constituir una relación laboral única, lo que se reitera después en la sentencia de 16 abril 1999 (RJ 1999\4424), donde se matiza que el resultante fraude de ley no implica siempre y en toda circunstancia, una actitud empresarial estricta y rigurosamente censurable, desde una perspectiva moral, social o legal ("dolus malus") sino la mera y simple consciencia de que la situación laboral contemplada no implica eventualidad alguna, sino que es una clara manifestación del desarrollo normal y habitual de la actividad gestionada» (F.D. 3ㅇ) ».

En el caso de nombramientos de carácter eventual puede resultar conveniente hacer las siguientes previsiones:

- Se hará constar en los nombramientos, con toda precisión, el servicio determinado que lo motiva. No se deberán utilizar expresiones genéricas tales como "acumulación de tareas", "necesidades del servicio", "necesidades de personal" o similares.

- Siempre que resulte posible se hará constar en los nombramientos las fechas de inicio y fin de la prestación del servicio para el que se nombra. De no conocerse esta última por la duración incierta del servicio a desarrollar, deberá desprenderse de la propia descripción del servicio determinado que posibilita el nombramiento.

- En todos los casos en que los nombramientos correspondan a servicios determinados de duración ( predeterminada o presunta por así derivarse del servicio) superior a un año, deberá obtenerse autorización especial, a cuyo fin se informará de las circunstancias que determinan la necesidad del mismo. Además debo llamar la atención sobre la previsión que realiza el Estatuto Marco del Personal Estatutario de los Servicios de Salud respecto del personal temporal con nombramiento de carácter eventual, de modo que si se realizarán más de dos nombramientos para la prestación de los mismos servicios por un 
periodo acumulado de doce o más meses en un periodo de dos años, procederá el estudio de las causas que lo motivaron, para valorar, en su caso, si procede la creación de una plaza estructural en la plantilla del centro.

Respecto al nombramiento eventual para la prestación de servicios de guardias, a favor de un profesional, en aquellos distritos y hospitales en que resulte necesario para garantizar la cobertura asistencial de esta actividad debo precisar, que este personal no ocupará plaza de plantilla, ni el nombramiento le otorga la condición de titular en propiedad de las Instituciones Sanitarias públicas.

Las causas que determinan la necesidad del nombramiento se harán constar expresamente en el contrato, pudiendo responder a: a) Necesidad derivada de exención de guardias por razón de la edad a los profesionales titulares de las plazas. b) Necesidad derivada de exención temporal de guardias a las profesionales titulares de plazas por razón de embarazo. c) Necesidad derivada de cualquier otra circunstancia que haga disminuir el número de profesionales disponibles para la realización de guardias.

Los nombramientos se mantendrán en vigor mientras subsistan las circunstancias que lo motivaron, siendo causa de extinción con el consiguiente cese del profesional nombrado, las siguientes: a) No superar el periodo de prueba, en aquellos casos en que no estuviera exento. b) Renuncia del interesado, que deberá formalizar por escrito con una antelación suficiente. c) Modificación de las circunstancias que motivaron la necesidad del nombramiento, incluida la posibilidad de nueva programación de las guardias. d) Cualquier otra que se derive de la legislación vigente.

El personal así nombrado percibirá como retribuciones exclusivamente las previstas para el resto de los profesionales como complemento de guardias, en las mismas cuantías y condiciones que el resto de los del centro que desempeñen esta actividad.

En el supuesto de los nombramientos de sustitución debo hacer notar que deberá entenderse que proceden cuando el personal a sustituir tenga precisamente la condición de sustituto, así como cuando sea necesario sustituir a personal laboral de plantilla.

Respecto del personal estatutario temporal en su conjunto determina que le será de aplicación, en cuanto sea adecuado a la naturaleza de su condición, el régimen general del personal estatutario fijo. 


\section{EL VÍNCULO DEL PERSONAL ESTATUTARIO DE LOS SERVI- CIOS DE SALUD Y LA COMPETENCIA JURISDICCIONAL}

\section{Justificación y utilidad de los antecedentes expuestos.}

La referencia histórica de la prestación de servicios profesionales en los centros sanitarios, la entrada en vigor de la Ley 55/ 2003, de 16 de diciembre, del Estatuto Marco del Personal Estatutario de los Servicios de Salud, el concepto, la naturaleza jurídica y la clasificación del personal estatutario, son los antecedentes imprescindibles para entender la trascendencia del problema que abordo, su correcta ubicación en el entorno de los trabajadores públicos y las consideraciones que se desprenden de su catalogación como un "tertium genus", a caballo entre los funcionarios y el personal laboral.

Su utilidad radica en poner de manifiesto que la situación no ha mejorado -hasta el momento- a pesar de la modificación sustancial del régimen jurídico de un colectivo que en nuestro país supera los 500.000 trabajadores.

\section{0 rigen del estudio que abordo en este trabajo: dos sentencias del Juzgado Contencioso-Administrativo núm. 7 de Madrid.}

Los profesionales sanitarios y demás colectivos de personal que prestan sus servicios en los centros e instituciones sanitarias de la Seguridad Social han tenido históricamente en España una regulación específica. Esa regulación propia se ha identificado con la expresión "personal estatutario" que derivaba directamente de la denominación de los tres Estatutos de Personal -el Estatuto de Personal M édico, el Estatuto de Personal Sanitario no Facultativo y el Estatuto de Personal no Sanitario- de tales centros e instituciones.

La conveniencia de una normativa propia para este personal surge de la necesidad de que su régimen jurídico se adapte a las específicas características del ejercicio de las profesiones sanitarias y del servicio sanitario-asistencial, así como a las peculiaridades organizativas del Sistema Nacional de Salud ${ }^{31}$.

Recientemente he podido leer dos sentencias del Juzgado ContenciosoAdministrativo núm. 7 de Madrid, cuya Magistrada Dạ Emilia-Teresa Díaz Fernández, declara la competencia jurisdiccional del orden social para conocer de la pretensión deducida en los procedimientos ordinarios 78/2002 N y

31 Vide Ley 55/ 2003, de 16 de diciembre, del Estatuto Marco del Personal Estatutario de los Servicios de Salud, Preámbulo. 
57/ 2002 C. Las cuestiones principales deducidas, en ambos, son idénticas y se resumen en una reclamación por concepto de horas de descanso no disfrutado de una determinada cantidad económica al INSALUD.

Inicialmente se presentó una reclamación previa ante la Dirección Territorial del INSALUD en materia de Derecho y Cantidad, que por resolución termina reconociendo parcialmente el petitum, y frente a la misma se interpone una demanda ante el Juzgado de lo Social que estimó parcialmente la pretensión. Formulado recurso de suplicación recayó sentencia del TSJ de Madrid, Sala de lo Social, cuyo tenor literal expresaba:

«Que debemos declarar y declaramos la in competencia material de este orden jurisdiccional social para el conocimiento y la resolución de la cuestión objeto de nivel procedimiental, por lo que debemos anular y anulamos, dejándola sin efecto, todo lo actuado en el mismo desde la providencia de admisión a trámite de la demanda, advirtiendo a las partes litigantes que podrán formular sus reclamaciones de cantidad ante los órganos judiciales de la jurisdicción del orden contencioso-administrativo que es la competente en esta materia. Sin que haya lugar a hacer pronunciamiento en costas contra ninguna de las partes litigantes».

La parte recurrente formuló recurso potestativo de reposición ante el INSALUD, sin que se resolviera de modo expreso.

La cuestión objeto de controversia de la pretensión formulada en la demanda configura "una reclamación de cantidad en concepto de horas de descanso no disfrutado por importe de [...] euros", debiéndose analizar si el Orden Jurisdiccional Contencioso-Administrativo resulta competente para el conocimiento del objeto controvertido. Cuestión sobre la que evidentemente no hay laguna del derecho que solventar ${ }^{32}$.

\footnotetext{
32 Vide Sentencia del Tribunal Superior de Justicia de La Rioja, núm. 71/ 1993, de 30 de abril (Sala de lo Social). AS 1993|1905:

«[... ]. Establecida la aplicación al personal estatutario, que presta sus servicios en las Instituciones Sanitarias de la Seguridad Social, de los correspondientes Estatutos Jurídicos del Personal Médico, del Personal Auxiliar Sanitario Titulado y Auxiliar de Clínica, y del Personal no Sanitario, preciso es determinar el procedimiento para la cobertura de los numerosas lagunas que en los mismos se aprecian.

Cuando se producen dichas lagunas, debe buscarse su integración en el ordenamiento jurídico a través de los mecanismos que el propio sistema establece, para poder cumplir el mandato del art. 1.7 del Código Civil, que impone a los Jueces y Tribunales el deber inexcusable de resolver en todo caso los asuntos de que conozcan, atendiéndose al sistema de fuentes. Así, aparte de la aplicación directa a la relación de servicios del personal estatutario de las normas específicamente dictadas para regularla (Estatutos Jurídicos del Personal ya citados; Real Decreto 137/ 1984, de 11
} 
El tema principal a decidir, debe contraerse al examen de la pretensión, por si del mismo pudiera inferirse que se trata del ejercicio de una acción de responsabilidad patrimonial o por el contrario, se trata de una acción de reclamación de cantidad derivada de las relaciones contractuales interpartes.

No debe desconocerse que la parte recurrente ha impetrado el auxilio jurisdiccional ante el Orden Contencioso-Administrativo, como consecuencia de la declaración de oficio de la incompetencia de jurisdicción, realizada por la Sala Social del TSJ de Madrid, en virtud de sentencia devenida definitiva y firme.

Sin embargo, este orden jurisdiccional no resulta competente en razón de la materia, pues claramente se vislumbra que no se trata de un supuesto de responsabilidad patrimonial, pues no se discute reclamación alguna por ausencia o indebida prestación del servicio que tiene confiado el INSALUD, por parte de algún beneficiario, cuyo anormal funcionamiento impone que los particulares hayan de ser indemnizados con las determinaciones que establece el art. 141.1 LRJPA ${ }^{33}$.

enero, y Real Decreto 521/ 1987, de 15 abril; normas sobre retribuciones, en particular el Real Decreto 3/ 1987, de 11 septiembre; sobre incompatibilidades, Ley 53/ 1984, de 26 diciembre (art. 2.은 1, f), y Real Decreto 598/ 1985, de 30 abril), también le es de aplicación supletoria la Ley 30/ 1984, de 2 agosto, de Reforma de la Función Pública, cuyo art. 1.5 dispone que «la presente Ley tiene carácter supletorio para todo el personal al servicio del Estado y de las Administraciones Públicas no incluido en su ámbito de aplicación» y obviamente las disposiciones del Código Civil, cuyo art. 4. 3 establece que «las disposiciones de este Código se aplicarán como supletorias en las materias regidas por otras leyes».

Cuando estas normas de aplicación supletoria tampoco contemplen el supuesto específico en cuestión, ha de acudirse al procedimiento analógico previsto en el núm. 1 del citado art. 4.0 del Código Civil ( «Procederá la aplicación analógica de las normas cuando éstas no contemplen un supuesto específico, pero regulen otro semejante entre los que se aprecie identidad de razón»). La aplicación de la analogía exige, por tanto, semejanza entre el supuesto de hecho no regulado y el regulado, y que los elementos esenciales que constituyen la «ratio iuris» de la norma se observen en el supuesto no regulado. De los dos tipos de analogía, la «legis» (aplicación de una norma singular al caso carente de regulación) y la «iuris» (aplicación de un principio general deducido de un conjunto de normas), es preferente el primero en virtud de la jerarquía de las fuentes establecida en el art. 1. del Código Civil, siendo sólo admisible la analogía «iuris» en último extremo, pues tal es el lugar que corresponde a los principios generales del derecho en el orden jerárquico de las fuentes. $\mathrm{H}$ a de señalarse, en consecuencia, que las disposiciones del Estatuto de los Trabajadores, y de las demás normas laborales sólo podrán ser aplicables al personal estatutario al servicio de la Seguridad Social, a través del procedimiento analógico, en ausencia de regulación susceptible de aplicación directa o supletoria» (F.J. 3o).

33 Vide Juan Francisco PÉREZ GÁLVEZ, "Responsabilidad por acto sanitario y progreso de la «ciencia» 0 de la «técnica»", REDA, 104, (1999), pp. 657-673. 
Sin embargo, los artículos 120-126 LRJPA posibilitan el ejercicio de acciones contra la Administración Pública, fundadas en derecho privado o laboral, siempre que traigan causa o motivo específico distintos de la responsabilidad derivada como consecuencia del funcionamiento del servicio público encomendado y por tanto resultará competente el O rden Jurisdiccional Civil o Social (art. 121 LRJPA) ${ }^{34}$. En este supuesto, será el Orden Jurisdiccional Social.

El grupo normativo regulador, en materia de competencia jurisdiccional, está configurado por las siguientes disposiciones: LOPJ, LJ, LGSS.

\section{Ley O rgánica del Poder Judicial.}

En particular debo citar al menos:

$$
\text { - Art. 9.1 LOPJ: }
$$

«Los Juzgados y Tribunales ejercerán su jurisdicción exclusivamente en aquellos casos en que les venga atribuida por esta y otra Ley».

- Art. 9.4 LOPJ (nueva redacción que establece la Ley Orgánica 19/ 2003, de 23 de diciembre, de modificación de la Ley Orgánica 6/ 1985, de 1 de julio, del Poder Judicial):

«Los del orden contencioso-administrativo conocerán de las pretensiones que se deduzcan en relación con la actuación de las Administraciones públicas sujeta al Derecho administrativo, con las disposiciones generales de rango inferior a la ley y con los reales decretos legislativos en los términos previstos en el art. 82.6 de la Constitución,

\footnotetext{
${ }^{34}$ Así lo ha puesto de manifiesto la Sala de Conflictos de Competencia del Tribunal Supremo, en Sentencia de 26 de junio de 1998: «EI Instituto Nacional de la Salud así como el resto de las entidades que ejercen funciones similares en las distintas Autonomías gozan de la naturaleza de entidades gestoras del correspondiente servicio público (artículos 57 a) y 59.1 del Texto Refundido de la Ley de Seguridad Social de 20 de junio de 1994), que desempeñan bajo la tutela y dirección del Estado, por lo que han de considerarse integrados con todas las consecuencias antedichas, en el concepto de Administración Pública [... ]. Ello supone, asimismo, que cualquier tipo de reclamación por indebida prestación del servicio que tiene confiado ha de ventilarse en vía administrativa y mediante el subsiguiente recurso contencioso, sin que ello signifique en absoluto mermar el contenido de la jurisdicción laboral en lo que se refiere a los múltiples aspectos que ofrece el campo de la reclamación de prestaciones de la Seguridad Social en relación con los derechos y obligaciones específicos que dimanan del contrato de trabajo; únicamente quiere decir, que se integran en el marco unitario del procedimiento administrativo, y su correspondiente secuela jurisdiccional, todas las prestaciones que supongan una reclamación por defectuosa prestación del servicio público que tiene confiado».
} 
de conformidad con lo que establezca la ley de esa jurisdicción. También conocerán de los recursos contra la inactividad de la Administración y contra sus actuaciones materiales que constituyan vía de hecho.

Conocerán, asimismo, de las pretensiones que se deduzcan en relación con la responsabilidad patrimonial de las Administraciones públicas y del personal a su servicio, cualquiera que sea la naturaleza de la actividad o el tipo de relación de que se derive. $\mathrm{Si}$ a la producción del daño hubieren concurrido sujetos privados, el demandante deducirá también frente a ellos su pretensión ante este orden jurisdiccional. Igualmente conocerán de las reclamaciones de responsabilidad cuando el interesado accione directamente contra la aseguradora de la Administración, junto a la Administración respectiva.

También será competente este orden jurisdiccional si las demandas de responsabilidad patrimonial se dirigen, además contra las personas o entidades públicas o privadas indirectamente responsables de aquéllas».

- Art. 9.5 LOPJ:

«Los del orden jurisdiccional social conocerán de las pretensiones que se promuevan dentro de la rama social del Derecho, tanto en conflictos individuales como colectivos, así como las reclamaciones en materia de Seguridad Social o contra el Estado cuando le atribuya responsabilidad la legislación laboral».

- Art. 9.6 LOPJ:

«La jurisdicción es improrrogable. Los órganos judiciales apreciarán de oficio la falta de jurisdicción y resolverán sobre la misma con audiencia de las partes y del Ministerio Fiscal. En todo caso, esta resolución será fundada y se efectuará indicando siempre el orden jurisdiccional que se estime competente».

\section{Ley de la Jurisdicción Contencioso-Administrativa.}

Por su parte la LJ determina en el art. 7.2:

«La competencia de los Juzgados y Salas de lo Contencioso-Administrativo no será prorrogable y deberá ser apreciada por los mismos, incluso de oficio, previa audiencia de las partes y del Ministerio Fiscal por plazo común de diez días».

\section{Ley General de la Seguridad Social.}

\subsection{El artículo 45.}

El artículo 45 del Texto Refundido de la Seguridad Social, establece: «Personal de las Entidades Gestoras. 
1. La relación entre las Entidades Gestoras y, en su caso, Servicios de la Seguridad Social y el personal a su servicio se regulará por lo previsto en los Estatutos de Personal aprobados por el Ministerio de Trabajo o, por el Estatuto general aprobado por el propio Ministerio.

2. Sin perjuicio del carácter estatutario de dicha relación la jurisdicción de trabajo será la competente para conocer de las cuestiones contenciosas que se susciten en tre las Entidades Gestoras y su personal, con excepción del comprendido en el número siguiente.

3. Los Estatutos a que se refiere el número 1 de este artículo preverán el libre nombramiento y separación de su personal directivo o que ocupe cargos de confianza.

Compete al Consejo de Ministros a propuesta del Ministro de Trabajo, el nombramiento y cese de los cargos directivos con categoría, determinada por Decreto, de Director General o asimilada».

El párrafo segundo, ha sido derogado por la disp. derog. 1ab) de la ley 30/ 1984, de 2 de agosto, de M edidas para la Reforma de la Función Pública, pero tal derogación, no afecta a los “Cuerpos y Escalas Sanitarias y Asesores Médicos" según establece la disp. adic. 16ạ de la referida Ley. Criterio que se mantiene en el nuevo Texto Refundido de la Ley General de la Seguridad Social, aprobado por RD 1/ 1994, de 20 de junio, pues su disposición derogatoria única a) 1, deja en vigor de forma expresa el citado art. 45 del Decreto 2065/ 1974.

\subsection{Excepción.}

En el número 3 del artículo 45 de la LGSS se determina el libre nombramiento y separación de su personal directivo o que ocupe cargos de confianza, siempre que ostenten la categoría que se determina en el mismo.

Sin duda constituye una excepción. Pero tal y como ha precisado la Sentencia del Tribunal Supremo, de 2 de abril de 2001 (Sala de lo Social) [R] 200114124], siempre que concurran las circunstancias que se contemplan en la misma, no en caso contrario:

«[... ] criterio de que la misma aplica el régimen del personal laboral especial de alta dirección a directivos de hospitales y centros sanitarios de la Seguridad Social que hayan sido contratados laboralmente, aunque no reúnan los requisitos y condiciones que impone el art. 1-2 del Real Decreto 1382/ 1985. Lo cual se corrobora plenamente por las normas legales que han venido a suceder a esa Disposición Final, esto es el art. 20-4 del Real Decreto-ley 1/ 1999 y la Disposición Adicional Décima, núm. 4, de la Ley 30/ 1999, las cuales determinan quienes son los concretos órganos de dirección de centros y establecimientos sanitario «[ ... ]. La única interpretación admisible de la norma que comentamos, es la que sienta el sa los que se aplica el indicado régimen especial, siendo incuestionable que ninguno de los cargos u órganos que estos preceptos mencionan, cumplen las condiciones y exigencias del art. 1-2 del Real Decreto 1382/ 1985. 
De lo expresado se deduce que, conforme a las disposiciones legales que se vienen comentando, la normativa reguladora del personal de alta dirección que se previene en el Real Decreto 1382/ 1985, se aplica a determinados directivos de centros sanitarios los cuales no cumplen en absoluto, los requisitos y presupuestos que, según el art. 1ㅇ de dicho Decreto, son necesarios para poder ser incluidos en el concepto de personal de alta dirección que esta norma establece. Pero esta realidad no supone que pueda sostenerse que aquellas disposiciones legales hayan vulnerado los mandatos de la Constitución, ni que se deba formular ante el Tribunal Constitucional cuestión de inconstitucionalidad con respecto a ellas. Se funda este criterio en las siguientes consideraciones:

1) --No existe razón alguna para poder afirmar que las normas antes reseñadas, es decir la Disposición Final Séptima de la Ley 31/ 1991, el art. 20-4 del Real Decreto-ley 1/ 1999 y la Disposición Adicional Décima, número 4, de la Ley 30/ 1999 infringen algún precepto de la Constitución.

2).-No puede hablarse de infracción del art. 14 de la misma, derivada de la comparación de las normas comentadas con el art. 10 del Estatuto de los Trabajadores, pues no existe entre esas normas y este art. 1 o ninguna clase de conflicto. En este caso nadie discute que la relación jurídica examinada sea un contrato laboral; se admite por todos la natural eza laboral de dicha relación; el tema del debate consiste en dilucidar si se trata de una relación de trabajo ordinaria o una relación de trabajo especial de alta dirección.

3).-Pero, tampoco en lo que concierne a este último dilema puede pensarse en que se conculque por las normas referidas el art. 14 de la Constitución, que en este caso tendría que derivarse de la confrontación de las mismas con el art. 2-1-a) del Estatuto de los Trabajadores. Este último artículo no especifica ni define el concepto de relación laboral especial de alta dirección, solamente hace alusión a ella; por consiguiente, no puede decirse que las comentadas normas contengan un tratamiento distinto al que prescribe dicho art. 2-1.

4). -La divergencia de tratamiento se produce entre las disposiciones a que se viene aludiendo, y el art. 1-2 del Real Decreto 1382/ 1985, pero este precepto tiene rango reglamentario, mientras que aquellas otras ostentan la condición y carácter de leyes formales. Es inaceptable basar la inconstitucionalidad de una Ley en el hecho de que sus mandatos sean distintos que los establecidos en un Decreto; en cualquier caso, ante tal disparidad, tendría que prevalecer la Ley sobre el Reglamento.

5).-Es más, el apartado i) del art. 2-1 del Estatuto de los Trabajadores extiende el concepto de relación laboral especial a «cualquier otro trabajo que sea expresamente declarado como relación laboral de carácter especial por una Ley». Y esto es, en definitiva, lo que han hecho las disposiciones legales comentadas, toda vez que lo que en ellas se hace realmente es otorgar la condición de relación laboral especial a la de los directivos de centros hospitalarios de la Seguridad Social. Sin que esta conclusión pueda entenderse desvirtuada por el hecho de que ese otorgamiento se efectúe mediante el sistema de remitirse a los mandatos del Real Decreto 1382/ 1985.

6).-Además, no puede olvidarse, en el discurso argumental que venimos exponiendo, que las relaciones profesionales de los cargos directivos de los hospitales y centros sanitarios de la Seguridad Social presentan unas especiales notas diferenciadoras, unas particularidades propias basadas en la específica importancia social de 
la función que desempeñan, que atañe a un área tan delicada y trascendente como es la sanidad y la salud pública y la protección sanitaria propia de la Seguridad Social, de tal modo que es obligado arbitrar medios adecuados para que el funcionamiento de las mismas sea lo más correcto y eficaz posible, dando facilidades para corregir con prontitud las disfunciones que en ellas se pudieran producir. En consecuencia, no puede descartarse que existan razones justificativas de un tratamiento diferenciado de los directivos mencionados, en relación con otros trabajadores» (F.D. 3o).

Aunque no afectará a los supuestos que no tienen esta naturaleza, tal y como determina la Sentencia del Tribunal Superior de Justicia de Murcia, núm. 193/ 2003, de 10 de febrero (Sala de lo Social) [JUR 2003/50508]:

«[...]. Es más, la Sala de conflictos de competencia del T.S., por auto de 19-102002, en un caso de provisión o promoción interna, viene a razonar literalmente lo que sigue: «Primero. Al ser el acto impugnado la decisión de la Dirección Provincial del INSALUD, de fecha $3 \mathrm{Feb}$. 1999, por la que se designa a una persona perteneciente al Grupo de Gestión de la Función Administrativa de Instituciones Sanitarias de la Seguridad Social (Grupo B), para la plaza de Director de Gestión y Servicios Generales en la Gerencia del Servicio de Emergencia 061, su conocimiento y resolución corresponde a la jurisdicción del orden contencioso-administrativo, dado que se trata de un supuesto de promoción interna de personal estatutario de naturaleza específicamente administrativa, siendo de aplicación lo establecido en la disp. dic. 7 de la L 30/ 1999, de 5 Oct., según la cual "L as convocatorias de los procedimientos de selección, de provisión de plazas y de movilidad a que se refiere esta Ley, así como sus bases, la actuación de los Tribunales y cuantos actos administrativos se deriven de ellas, podían ser impugnados por los interesados en los casos y en la forma previstos con carácter general en las normas reguladoras del procedimiento administrativo y de la jurisdicción contencioso-administrativa. Segundo. En consecuencia, y de acuerdo con el dictamen del Ministerio Fiscal, procede deferir el conocimiento de la demanda presentada al orden jurisdiccional contencioso-administrativo» » (F.D. 2º$)$.

\subsection{La derogación del art. 45 LG SS: una reforma que no llega a materia- lizarse.}

Siguiendo el procedimiento legalmente establecido para la elaboración de una disposición como el Estatuto Marco del Personal Estatutario de los Servicios de Salud, se efectuaron sendos informes-dictámenes por parte del Consejo General del Poder Judicial y del Consejo de Estado.

\section{A. Informe del Consejo General del Poder Judicial.}

El primero -del Consejo General del Poder Judicial-se pronuncia sobre el art. 45 del Texto Refundido la Ley General de la Seguridad Social, pues en la 
disposición derogatoria se enumeran las normas que quedarán derogadas a la entrada en vigor de la nueva ley, entre las que cabía citar este artículo (luego no fue así), relativo a la atribución a la jurisdicción social de la competencia para juzgar los conflictos que se produzcan entre el personal estatutario y los servicios de salud. Lo hace en los siguientes términos ${ }^{35}$.

- Se trata de una relación funcionarial especial, cuya competencia se pretende atribuir a la Jurisdicción Contencioso-Administrativa:

«En efecto, como ya se ha indicado, la ley proyectada deroga el artículo 45 del Texto Refundido de la Ley General de la seguridad Social aprobado por Decreto 2065/ 1974, de 30 de mayo, precepto éste que el ulterior y actualmente vigente Texto Refundido de esta misma ley, aprobado por Real Decreto Legislativo 1/ 1994, de 20 de junio, no derogó. Según el apartado 2 del todavía vigente artículo 45 del Texto Refundido de 1974, cuya derogación se dispone ahora en el anteproyecto objeto del presente informe, "sin perjuicio del carácter estatutario de dicha relación (se refiere a la del personal al servicio de las Entidades Gestoras y Servicios de la Seguridad Social), la Jurisdicción de Trabajo será la competente para conocer de las cuestiones contenciosas que se susciten entre las Entidades Gestoras y su personal". Pues bien, la derogación

35 El Secretario del Consejo General del Poder Judicial, certifica que el pleno en su reunión del día 29 de abril de 2003 ha aprobado el informe sobre el Anteproyecto de Ley del Estatuto Marco del Personal Estatutario de los Servicios de Salud, y como antecedentes figura:

«Por oficio de 15 de abril de 2003, que tuvo entrada en el Consejo General del Poder Judicial el mismo día, la Excma Sra. Ministra de Sanidad y Consumo, de acuerdo con lo establecido en el artículo 108.1 de la Ley Orgánica 6/ 1985, de 1 de julio, del Poder Judicial, solicitó de este Consejo la emisión de informe sobre el Anteproyecto de Ley del Estatuto Marco del Personal Estatutario de los Servicios de Salud.

La Comisión de Estudios e Informes, en su reunión del día 24 de abril de 2003, designó ponente del presente Informe al Exmo Sr. Vocal D. José Luis Requero I báñez, aprobándose éste, para su remisión al Pleno, en la misma sesión».

El objeto de esta disposición se resume del siguiente modo:

«La ley cuyo anteproyecto se somete a informe de Este Consejo tiene por objeto actualizar y adaptar el régimen jurídico del personal estatutario de los Servicios de Salud que conforman el Sistema Nacional de Salud, tanto en lo que se refiere al modelo del Estado autonómico como en lo relativo al concepto y alcance actual de la asistencia sanitaria. Tal es el objetivo que afronta el anteproyecto de ley sometido a informe de este Consejo, a través del establecimiento de las bases reguladoras de la relación funcionarial especial a que se halla sujeto el mencionado personal y mediante la correlativa aprobación de su Estatuto Marco, todo ello conforme a las previsiones del artículo 149.1.18a de la Constitución, en cuya virtud las normas de dicho Estatuto constituirán las bases del régimen estatutario de este personal de los Servicios de Salud. Se actualiza de este modo la normativa específica de carácter básico por la que se rige el personal estatutario que presta sus servicios en los centros e instituciones sanitarias de la Seguridad Social, con respeto tanto de las competencias para su desarrollo por las Comunidades Autónomas como del objetivo global de impulsar la autonomía de gestión de los citados Servicios, Centros e Instituciones». 
proyectada de esta previsión comporta lógicamente, tal y como destaca la propia Exposición de Motivos del anteproyecto de ley informado, que "la competencia para la resolución de tales conflictos queda(rá) atribuida a la Jurisdicción Contencioso-Administrativa, de forma coherente con la definición contenida en el artículo 1 de la Ley, del régimen jurídico del personal estatutario como una relación funcionarial especial"».

- El personal estatutario de la Seguridad Social ha constituido una de las Ilamadas zonas grises entre el orden contencioso-administrativo y el orden social:

«Como es sabido, durante años el llamado personal estatutario de la Seguridad Social ha constituido una de las Ilamadas zonas grises entre el orden contencioso-administrativo y el orden social, dando lugar a que se hablase de una categoría específi$\mathrm{ca}$, un tertium genus entre el personal funcionario y el laboral al servicio de las instituciones sanitarias de la Seguridad Social».

- Existe un problema denominado: "peregrinaje de jurisdicciones" que ha sido objeto de depuración.

«Es manifiesto que todo panorama de indefinición competencial en lo que a órdenes jurisdiccionales se refiere, no es bueno. De ahí que, en última instancia y para evitar lo que se ha dado en llamar peregrinajedejurisdicciones, la solución definitiva se haIle en manos del legislador. En efecto, por encima de razonamientos doctrinales que, de ordinario, intentan buscar la quintaesencia sustantiva o material a cierta relación jurídica, es el legislador quien puede zanjar tales disquisiciones, lo que es saludable más que nada desde el punto de vista de la seguridad jurídica.

Como se acaba de señalar, uno de esos terrenos de indefinición ha venido siendo el personal estatutario al que este dictamen hace referencia. Sentencia a sentencia, el Tribunal Supremo, tanto la Sala de lo Contencioso-administrativo como la de lo Social, ha ido depurando dicho régimen jurídico, reconociendo ciertamente que se está ante un régimen que guarda indiscutible similitud con el del personal funcionario al servicio de las Administraciones públicas y que la vinculación de Derecho público prepondera sobre la estrictamente laboral. De ahí, por cierto, que se hablase de una exclusión implícita del artículo 1.3.a) del Estatuto de los Trabajadores».

\section{- La doctrina de actos separables se aplica a esta materia:}

«No obstante ese carácter predominantemente público, la jurisprudencia ha ido recortando aspectos del régimen jurídico del citado personal estatutario, y ello sobre la base de una suerte de doctrina de actos separables aplicada a esta materia. Así, por ejemplo, se ha venido entendiendo que es propio del orden conten cioso-administrativo todo lo relativo al nacimien to y extinción de la relación estatutaria -a partir de ahora enteramente funcionarial- así como el ejercicio de la potestad sancionadora. Por el contrario, al orden so- 
cial se venía atribuyendo el conocimiento de los litigios referidos a la relación estatutaria o funcionarial ya existente. Pero, aun así, Ias excepciones a esa regla han sido numerosas y, valga como ejemplo, se ha atribuido al orden contencioso-administrativo el conocimiento de materias diversas, como el régimen de incompatibilidades, la adjudicación de plazas en concurso abierto, conflictos y convenios colectivos, etc».

- Se pretende la atribución de esta materia a su jurisdicción natural.

«Por consiguiente, este Consejo General no puede sino valorar favorablemente el que la competencia jurisdiccional para conocer de cuestiones atinentes a una relación de naturaleza funcionarial y por ello regida por el Derecho público se atribuya globalmente a su Jurisdicción natural, la Jurisdicción Contencioso-Administrativa. Aclarada y precisada definitivamente por la ley proyectada la genuina naturaleza jurídico-administrativa de la relación que une al personal estatutario de los Servicios de Salud con sus respectivas Administraciones, carecería de todo sentido, a juicio de este Consejo General, mantener en lo sucesivo la atribución de competencia en favor de la Jurisdicción social prevista en el Texto Refundido de la L ey General de la Seguridad Social de 1974. Asumida cabalmente la premisa de que la relación estatutaria del personal que presta servicios en los centros e instituciones sanitarias de la Seguridad Social constituye una mera especie del género funcionarial, no cabe en rigor una atribución de competencia jurisdiccional distinta de la que con pleno acierto prevé ahora el anteproyecto de ley objeto del presente informe».

- La reforma puede suponer una enorme carga de trabajo para la jurisdicción contencioso-administrativa:

«La última observación que procede hacer al texto informado se refiere al impacto que la reforma puede suponer para la carga de trabajo de los órganos contencioso-administrativos. Asumida ya la competencia que recae en ellos por las razones antes expuestas, la cuestión radica en determinar en que medida se incrementarán los litigios de los que conocen los Juzgados de lo Contencioso-administrativo y los Centrales si el acto impugnado proviene de losórganos centrales de las Entidades Gestoras de la Seguridad Social. En este sentido, y sin merma del parecer expuesto, favorable a la reforma en lo que tiene de clarificación, sí que procede advertir de que toda nueva atribución jurisdiccional -y dentro de ella, competencial- debe hacerse con especial precaución desde el punto de vista de la atribución de nuevas competencias y consiguiente carga de trabajo de los órganos judicial es afectados. De esta forma, este Consejo acaba de informar el anteproyecto de Ley de disposiciones específicas en materia de Seguridad Social y el anteproyecto de reforma de la Ley O rgánica del Poder Judicial, textos ambos que prevén incrementar las competencias de los Juzgados de lo Contencioso-Administrativos, tanto de los Centrales como de los provinciales».

- Por ello, el Consejo General del Poder Judicial plantea que esta alteración competencial debería ser objeto de un proyecto específico: 
«Así las cosas, en ese segundo informe decíamos que "quizá sean estas circunstancias las que aconsejen que una alteración competencial de los órganos de lo contencioso-administrativo salga de una Disposición Adicional para que sea objeto de un proyecto específico en el que se analicen las con secuen cias que implicará sobre la distribución del trabajo en estos órganos".

Esta observación debe mantenerse en el presente informe. No parece aconsejable que las alteraciones competenciales se hagan en textos aislados procedentes de diversos Ministerios; más bien lo oportuno es realizar un planteamiento global que proporcione una idea cabal de las consecuencias de esas alteraciones. De ahí que, desde ed punto devista del impacto judicial dela reforma informada, este Con sejo su giera que se contemple desde un análisis global de las iniciativas planteadas».

\section{B. EI dictamen del Consejo de Estado.}

El dictamen del Consejo de Estado aprobado el 14 de mayo de $2003^{36}$ hace referencia al informe emitido por el Consejo General del Poder Judicial. En base a estos antecedentes, el Consejo de Estado emite la siguiente consideración:

«Por ello, nada puede objetarse, desde el punto de vista estricto de la legalidad, a la derogación del artículo 45 de la Ley General de la Seguridad Social que de hecho supone el cambio del orden jurisdiccional tradicional. Tan sólo cabe señalar que, siendo este cambio tan relevante, quizás sería mejor hacerlo no de manera indirecta (por derogación de este artículo 45, resaltada -eso sí- en el último párrafo de la Exposición de Motivos), sino introduciendo un artículo en el Capítulo I (Normas Generales), que simplemente señale que corresponderá a los juzgados y tribunales del orden jurisdiccional de lo contencioso-administrativo conocer de las pretensiones que se deduzcan en relación con las relaciones entre las Administraciones Públicas y el personal estatutario comprendido en el ámbito de la presente Ley o fórmula similar.

Cuestión distinta es si resulta o no conveniente, desde el punto de vista de la oportunidad, hacer las previsiones necesarias para que el orden contencioso-administrativo pueda acometer esta nueva función con la celeridad e inmediatez con que tradicionalmente se enjuiciaban estas situaciones en el orden social o con la eficacia necesaria sobre la base de la carga de trabajo existente en la actualidad. El informe del Consejo General del Poder Judicial pone de relieve la inconveniencia que puede suponer no regular detalladamente en una Ley los cambios requeridos para el funcionamiento de estos nuevos servicios (todo aumento de competencia supone algún cambio, aunque sólo sea el del mero aumento del trabajo) en la Administración de Justicia entendida co-

${ }^{36}$ Número de expediente: 1492/ 2003 (Sanidad y Consumo). Asunto: Anteproyecto de Ley del Estatuto Marco del Personal Estatutario de los Servicios de Salud, por la que se incorporan al ordenamiento interno, en lo que se refiere a las competencias de este Departamento, las Directivas 93/ 104/ CE y 2000/ 34/ CE. 
mo servicio público. Ciertamente no existe en el expediente de tramitación del proyecto ningún estudio acerca de cuántos juicios se están tramitando en la actualidad sobre estas cuestiones ante los juzgados de lo social, ni cómo va a incidir su traspaso en la carga de trabajo que actualmente tienen los distintos juzgados y tribunales de lo contencioso-administrativo. Tampoco ha informado el proyecto el Ministerio de Justicia.

Ello no obsta para que el proyecto deba tramitarse, pero habría sido de desear la existencia de informes ( o simplemente de información) en el expediente, a los efectos de poder evaluar correctamente el impacto de la Ley en los servicios de la Administración de Justicia y de poder hacer recomendaciones de mejora del texto que, siendo el expediente el que es, no pueden hoy por hoy hacerse (en ningún sentido, ya que quizás el impacto es mínimo o asumible, pero simplemente se desconoce).

En cualquier caso, sí que se echa de menos una disposición transitoria señalando con detalle cómo afecta a las pretensiones y/ o vías previas, procedimientos y procesos en curso la derogación del artículo 45 del texto refundido de la Ley General de la Seguridad Social ( y al nuevo artículo en el que se atribuyen estos asuntos a la jurisdicción contencioso-administrativa)».

\section{El debate en sede parlamentaria del Estatuto Marco del Personal Esta- tutario de los Servicios de Salud.}

El propio debate parlamentario del Estatuto Marco del Personal Estatutario de los Servicios de Salud nos da algunas claves de este intento de derogación del art. 45 LGSS que finalmente no llega a producirse.

- En la Exposición de Motivos (Preámbulo).

En las enmiendas al articulado (BOCG, Congreso de los Diputados, Serie A: Proyectos de Ley, 3 de julio de 2003, Núm. 151-5), el Grupo Parlamentario Vasco (EAJ-PNV) propone una enmienda de adición ( Núm. 14), para añadir un nuevo párrafo al final de la exposición de motivos, con el siguiente contenido:

«De entre todo ello merece ser destacada la derogación del artículo 45 de la Ley General de la Seguridad Social, que atribuía a la Jurisdicción social la competencia para resolver los conflictos planteados entre el personal estatutario y los Servicios de Salud. De esta forma, la competencia para la resolución de tales conflictos queda atribuida a la Jurisdicción Contencioso-Administrativa, de forma coherente con la definición, contenida en el artículo 1 de la Ley, del régimen jurídico del personal estatutario como una relación funcionarial especial» ${ }^{37}$.

\footnotetext{
37 La justificación es la misma que la expresada en la enmienda núm. 13, que reproduzco a continuación.
} 


\section{- En la Disposición Derogatoria Única.}

En el mismo BOCG donde se recoge la enmienda Núm. 14 expuesta en el apartado anterior, se publica la enmienda Núm. 13, presentada por el Grupo Parlamentario Vasco (EAJ-PNV), donde se desea añadir un nuevo apartado a la disposición derogatoria única:

«h) El artículo 45 de la Ley General de la Seguridad Social texto refundido aprobado por Decreto 2065/ 1974, de 30 de mayo»38.

\section{VII.EL PRONUNCIAMIENTO DE LA JURISPRUDENCIA}

\section{Resolución adoptada en casos similares.}

Para casos similares los tribunales han determinado:

- La competencia de la Jurisdicción Contencioso-Administrativa en los supuestos legalmente encomendados. Sirva como ejemplo la sentencia del Tribunal Superior de Justicia de Madrid, núm. 617/ 2000, de 30 de diciembre (Sala de lo Social, Sección 1a) [AS 2001/729]:

«[...]. En suma, la ausencia de un pacto o acuerdo con la representación de los empleados, determinó la actuación de los mecanismos propiamente administrativos en aras de dotar al servicio público de acuerdo a los intereses generales a proteger, dán-

${ }^{38}$ La justificación es la siguiente: «En coherencia con la definición contenida en el artículo 1 de esta Ley que establece la relación funcionarial especial del personal estatutario de los Servicios de Salud, parece obvio atribuir a la jurisdicción Contencioso-Administrativa la competencia para resolver los conflictos planteados entre el personal estatutario y los Servicios de Salud, para lo que es necesario derogar este artículo de la Ley General de la Seguridad Social.

Al mismo tiempo, tanto el informe del Consejo de Estado como el del Consejo General del Poder Judicial valoran favorablemente la competencia Contencioso-Administrativa de las cuestiones atinentes a una relación de naturaleza funcionarial y, por ello, regida por el Derecho Público.

Siendo en este caso, por lo tanto, su jurisdicción "natural"».

En idéntico sentido se pronuncia la enmienda núm. 250 presentada por el Grupo Parlamentario Catalán (Convergencia y U nió), aunque en este caso se solicita la modificación del apartado a) de la Disposición Derogatoria Ú nica, que incluye también el art. 84. 1, 2 y 3 de la LGS.

La enmienda presentada por el PNV se reitera en el Senado, tal y como aparece en el BOGC, Senado, de 14 de octubre de 2003, enmienda Núm. 76, con el mismo texto y justificación presentados en el Congreso. Idéntica solución adopta Convergencia i U nió en el Senado a través de la enmienda Núm. 209. 
dose la circunstancia de que a tal actuación administrativa se adjuntaron o unieron las voluntades de los sindicatos ya mencionados -CC 00 y CEMS-, adjunción o unión que no desvirtuó en absoluto la naturaleza jurídica del acto en sí. [ ... ].

6.7. En el presente caso, además de lo ya dicho y razonado hasta ahora, es obvio que nos encontramos ante un supuesto en el que lo impugnado, bien sea un puro acto administrativo, bien sea la preparación del mismo mediante otros de trámite, corresponde ser fiscalizado por la Jurisdicción contencioso-administrativa, tal y como se desprende paladinamente de lo que prevé el artículo 3 de la Ley Procesal Laboral de 7 de abril de 1995, sea en su redacción originaria, caso en el cual hay que referirse a su letra a), sea en la que impuso la disposición adicional quinta de la Ley 29/ 1998, de 13 de julio, reguladora de la Jurisdicción Contencioso-Administrativa, supuesto en el cual hay que referirse a su letra $c$ ), sin que las salvedades que tal letra impone, desarrolladas o, más bien, fijadas en el punto 2 de la nueva redacción del artículo 3 procesal laboral por dicha Ley de 1998, alcancen a lo tratado en la presente litis, pues ni la misma trata sobre sanciones por infracciones del orden social, ni sobre resoluciones administrativas referentes a la regulación de empleo y actividad administrativa en materia de traslados colectivos.

Difíciles y complejas son y han sido las fronteras competenciales entre las Jurisdicciones Contencioso-Administrativa y Social, mas lo cierto es que el supuesto concreto que ahora tratamos es obvio que pertenece al marco competencial de la primera de las citadas, por cuanto, aunque su trasfondo sea laboral -estatutario en este caso-, así como sus consecuencias, se trata de un acto administrativo, en preparación o ya verificado, cuya fiscalización no corresponde a lo Social» (F.D. 3o).

- La competencia de la Jurisdicción Social en los supuestos encomendados, con las excepciones legalmente admitidas. Sirva como ejemplo el auto del Juzgado de la Social de Granada, de 5 de marzo de 2002 (Núm. 5) [AS 2002/1270], donde se pone de manifiesto un progresivo encauzamiento hacia la jurisdicción contencioso-administrativa:

«Frente a la petición cautelar prevista en el artículo $727.7^{\circ}$ de la nueva Ley de Enjuiciamiento Civil que se contiene en el mismo escrito de demanda, se excepcionó, con carácter previo, por el letrado del Servicio Andaluz de Salud la incompetencia de jurisdicción por razón de la materia, que debe ser estudiada con carácter previo. Y, en este sentido la doctrina que la Sala de lo Social del Tribunal Supremo mantiene, en relación con el personal estatutario de la Seguridad Social, arranca de una afirmación de principio: el artículo 45 de la Ley de Seguridad Social de 1974, cuya vigencia para el personal estatutario sigue siendo indiscutible por imperativo de la disposición adicional 7ạ. Única a).1 de Real Decreto Legislativo 1/1994, de 20 de junio, pese a la promulgación de la Ley 30/1984, de 2 de agosto y del Real Decreto 118/1991, de 25 de enero (Sentencia del Tribunal Supremo de 5 de noviembre de 1993 [RJ 1993| 8551]), contiene una cláusula de atribución competencial al orden social de todas las cuestiones litigiosas que surjan entre la Entidad Gestora y el personal estatutario a su servicio. No obstante, el Tribunal Supremo ha admitido la existencia de excepciones a la competencia de orden social, formadas históricamente, como señala autorizada doctrina, en torno a las re 
servas de competen cia de la Administración del Estado frente al fenómeno gen eral de descentralización institucional dela gestión de la Seguridad Social, quenaturalmente supone a su vez la del régimen de personal que presta servicios para el propio organismo rector. Y son éstas las relacionadas con las decisiones en materia de régimen disciplinario y de provisión de vacantes ${ }^{39}$. [ ... ].

\footnotetext{
39 Sobre esta cuestión el propio Auto del Juzgado de los Social de Granada, de 5 de marzo de 2002 dispone: «[... ] Respecto de esta última excepción, el Tribunal Supremo ha venido mantenien do la línea jurisprudencial que inició en su Sentencia de 5 de noviembre de 1993, dictada ciertamenteen relación con un concurso permanente y abierto, pero en la que se exponía una doctrina válida también para los concursos internos en los que no participa personal ajeno al Instituto $\mathrm{Nacional}$ de Salud (Insalud). En ella, con invocación a su vez de varias sentencias anteriores, declaró ya que era el orden Contencioso-Administrativo el competente para conocer de la materia relativa a la convocatoria de concursos selectivos en el ámbito del personal estatutario de la Seguridad Social. Esa línea fue posteriormente seguida en las Senten cias de 11 de noviembre de 1993 (RJ 1993। 8679), y 4 de febrero (RJ 1994\ 794) y 23 de diciembre de 1994 (RJ 1994\10503), y de finitivamente clarificada, para su ámbito de aplicación, por la Sentencia de 29 de abril de 1996 (RJ 1996) 4137), dictada con ocasión de un concurso interno convocado al amparo del Real Decreto 118/1991, hoy ya derogado. En esta última sentencia se afirma que: «La atribución de competencia que contiene el artículo 45 de la L ey de Seguridad Social de 30 de mayo de 1974 se refiere a las cuestiones contenciosas que puedan surgir entre las Entidades Gestoras y el personal a su servicio en la aplicación e interpretación de las normas reguladoras de la relación estatutaria, pero no se extien de a la impugnación directa de estas normas, que tanto cuando se establecen directamente a través de la potestad reglamentaria, como cuando lo son a través de los instrumentos de negociación regulados en la L ey $9 / 1987$, han de ser impugnados ante el orden Conten ciosoAdministrativo de la jurisdicción. Por otra parte, la materia a la que se refiere la impugnación, que afecta a los criterios de selección del personal estatutario, ha quedado fuera del ámbito del orden social de la jurisdicción... y ello tanto si afectan a la selección de personal de nuevo ingreso, como si se refiere a concursos de promoción interna (Sentencias de 5 y 11 de noviembre de 1993, 4 de febrero, 25 de abril [R] 1994\3456] y 23 de diciembre de 1994)...».

Criterio seguido luego, literalmente, por los Autos de 16 de diciembre de 1997 (RJ 1998\1336) de la Sala Especial de Conflictos de Competencia y de 9 de julio de 1998 de la Sala Cuarta del Tribunal Supremo y recogido también en las Sentencias de 17 de noviembre de 1997 (RJ 1997 8315), 31 de mayo de 1999 (RJ 1999\5006) y 4 de octubre de 2000 (RJ 2000\8661), esta última dictada en Sala General en relación con el mejor derecho a ser contratado temporalmente en proceso de selección de personal de acuerdo con previas listas confeccionadas por la Entidad Gestora, y que en la actualidad ha sido acogido expresamente por el legislador, en la Ley 30/ 1999, de 5 de octubre, cuya disposición adicional séptima, atribuye al orden Contencioso-Administrativo el conocimiento de las demandas de impugnación de «las convocatorias de los procedimientos de selección de provisión de plazas y de movilidad a que se refiere esta Ley así como sus bases, la actuación de los Tribunales y cuantos actos administrativos se deriven de ellas». De ahí que la Sala Especial de Conflictos de Competencia del Tribunal Supremo, en Auto de 16 de junio de 2001 para supuestos de promoción interna de personal Estatutario ha declarado la competencia del orden Contencioso-Administrativo. Ahora bien, las normas de atribución al orden Contencioso-Administrativo por su carácter excepcional, en cuanto limitan la competencia que, con carácter general, corresponde al orden social por mandato del artículo 45.2 de la Ley de Seguridad Social de 1974, no pueden ser objeto de una interpretación extensiva. Tanto el Real Decreto 118/ 1991, como el posterior Real Decreto Legislativo 1/ 1999, dictado por razones de urgencia para evitar la paralización de convocatorias amparadas en el primero, una vez que aquél había sido anulado por
} 
Es cierto que el Tribunal Supremo viene reiterando en relación con el personal estatutario de la Seguridad Social la inaplicación a dicha relación estatutaria de las normas laborales por la especial naturaleza de la vinculación jurídica que tiene este colectivo -artículo 1.3 a) del Texto Refundido del Estatuto de los Trabajadores-. Así, la jurisprudencia desde antiguo les excluye de la aplicación del derogado artículo 23.3 del Estatuto de los Trabajadores de 1980 y de los plazos de prescripción que se recogen en el artículo 59 de la misma norma. Recientemente el Tribunal Supremo ha venido declarando la existencia de nulidad en los ceses, por aplicación del artículo 6.3 del Código Civil, rechazando la aplicación de los preceptos relativos al despido disciplinario (Sentencia del Tribunal Supremo de 7 de junio de 2000 [RJ 2000। 5106]); el no reconocimiento de los beneficios del derogado artículo 25.2 de la Ley de Procedimiento Laboral -hoy artículo 2 b) de la Ley $1 / 1996$ sobre justicia gratuita-; la sentencia de 5 de junio de 2000 (RJ 2000 4649) les excluye de la aplicación del artículo 138.4 sobre procesos de modificación sustancial de condiciones de trabajo. Con estas sentencias se va reduciendo el ámbito procesal laboral aplicable al personal estatutario, remitiendo todas o casi todas las cuestiones al proceso ordinario, pronunciamientos que vienen poniendo de manifiesto una constante reflexión sobre el lugar de la jurisdicción social en el enjuiciamiento de las cuestiones que afecta a este personal de la Seguridad Social y

sentencia de la Sala Tercera del Alto Tribunal, contenían ya un implícito límite competencial que, en la actualidad, ha quedado expresamente recogido en la disposición adicional séptima de la posterior Ley 30/ 1999, transcrita literalmente en el párrafo anterior. Por consiguiente, la competencia de los tribunales del orden Contencioso-Administrativo se circunscribe a los actos de provisión de vacantes acordados conforme a los sistemas que la propia Ley establece. No cabe duda pues que el ámbito material de aplicación de las normas invocadas, incluida la Ley 30/ 1999, que es la más explícita al respecto, no puede extenderse más allá de las cuestiones relativas a lo que el artículo 10 y la adicional séptima de la Ley 30/ 1999 denomina «procedimientos de movilidad» y que su artículo II identifica como «traslados» que vienen a constituir el escalón último del sistema de provisión de plazas como se infiere del artículo 10 de la Ley, y que coinciden con los que el Real Decreto 118/ 1991 Ilamaba «concurso de traslados», que tienen por objeto la «provisión de las plazas básicas de cada categoría». O lo que es igual, llega hasta los mecanismos de cobertura por medio de la movilidad, coincidentes con lo que en el mundo laboral se conocen como supuestos de «movilidad geográfica» que implican o bien el acceso a una plaza en propiedad distinta de la de destino en el propio Servicio de Salud o bien el pase a otro Servicio distinto (artículo II.3). Pero ni el Real Decreto 118/ 1991 ni las demás normas citadas, sustraen del orden social el conocimiento de los actos de gestión de personal estatutario llevados a cabo dentro o fuera del Área de Salud a la que dicho personal en propiedad está adscrito por mandato del artículo 87.1 de la Ley 14/ 1986, de 25 de abril, General de Sanidad. Estos deben seguir la regla general de competencia del artículo 45 de la Ley de Seguridad Social, que es lo que acontece en el caso enjuiciado, en que se pide la suspensión cautelar no en relación con una provisión de plazas vacantes por alguno de los mecanismos de cobertura que establece la Ley 30/ 1999, sino en relación con un acuerdo o decisión empresarial de desplazar a la actora en base a una supuesta facultad de dirección o gestión del organismo demandado, que tiene que ser resuelta por este Orden Social conforme al mandato del artículo 45.2 de la Ley de Seguridad Social de 1974 [ ... ] (F.D. ÚNICO)». 
un aconsejable encauzamiento de las mismas de manera unitaria hacia el orden contencioso-administrativo, reflexión que, sin embargo, sólo se hace aquí «de lege ferenda», pues «lege data», como se ha dicho, hay cuestiones que se ven en el orden contencioso-administrativo y otras, como acontece en la cuestión enjuiciada, que sigue siendo competencia del orden social» (F.D. Ú NICO).

También esa evidencia se determina en el supuesto de plazas laborales de nuevo ingreso o plazas de promoción interna, pues una vez concluido el proceso selectivo y hecha la propuesta de contratación, tanto ésta como los actos administrativos que la sigan están sujetos al Derecho del Trabajo y son, impugnables ante el Orden Social, tal y como precisa la sentencia del Tribunal Superior de Justicia de Canarias, Santa Cruz de Tenerife, núm. 226/ 2002, de 25 de abril (Sala de lo Social) [ AS 2002|2085]:

«[...]. En cuanto al personal laboral al servicio de la administración, vemos que está vinculado por un contrato de trabajo, por ello lo normal es que la competencia para conocer de las posibles controversias que surjan a propósito de esa relación esté atribuida al orden social. Pero se plantea la cuestión de cuándo la Administración actúa sujeta al Derecho Administrativo y cuándo al Derecho del Trabajo. El Tribunal Supremo en las cuestiones que se plantean y surgen a propósito del personal laboral al servicio de las Administraciones Públicas ha matizado distinguiendo aquellos supuestos en los que la Administración oferta «plazas laborales de nuevo ingreso» y cuando se trata de «plazas de promoción interna». En el primer caso, subraya, «aunque la Administración convocante es la que luego ha de contratar, su actuación es previa al vínculo laboral y predomina en ella el carácter público en los términos fijados por la Ley ... Se trata pues de actos administrativos sujetos al Derecho Administrativo». Una vez ha concluido el proceso selectivo y hecha la propuesta de contratación, tanto ésta como los actos administrativos que la sigan están sujetos al Derecho del Trabajo y son, en consecuencia, impugnables ante el Orden Social. H ay ya un contrato de trabajo perfeccionado y la Administración actúa como empresario.

Cuando la Administración oferta plazas de promoción interna, tiene que desarrollar procedimientos selectivos internos cuando ya existen unas relaciones laborales que vinculan a ésta como empleadora, es decir, que todo se encuentra dentro del marco de unas relaciones laborales preexistentes. Si la Administración incumple dichas normas de promoción interna dicho incumplimiento relaciona al trabajador frente a la administración empresaria» (F.D. 2ํㅜ).

\section{Resolución adoptada por la Sala Especial de Conflictos de Competencia del Tribunal Supremo de España.}

El Conflicto de Competencia Social y Contencioso núm. 43/2002, en el conflicto de competencia suscitado entre el Juzgado de lo Contencioso-Administrativo $\mathrm{N} 7$ en el procedimiento Ordinario núm. 78/ 2002, al que hice refe- 
rencia, es resuelto mediante el Auto núm. 4/ 2003, de 7 de abril, en los siguientes términos ${ }^{40}$ :

«N os hallamos ante una relación, la estatutaria, entre el Insalud y el personal facultativo a su servicio que, en no pocas ocasiones, ha dado lugar a una escisión de competencias entre ambas jurisdicciones por lo que no es nueva la situación de que una misma relación genere situaciones cuyas controversias puedan ser sustanciadas en órdenes jurisdiccionales diferentes, así, como ejemplo, cabe citar las reclamaciones sobre cobertura de vacantes y convocatoria de concursos a propósito de las cuales hay numerosas sentencias del Tribunal Supremo [...]. La reclamación que los actores plantean está inmediatamente ligada al conjunto de derechos y obligaciones derivadas del vínculo estatutario. De igual modo que constituye responsabilidad patrimonial de las Administraciones Públicas el pago a sus trabajadores no funcionarios de salarios e indemnizaciones por despido, obligaciones que sobre la Administración pesan en su calidad de empleadora, de suerte que la Ley de Procedimiento Laboral en su artículo 2-a) declara la competencia de la jurisdicción laboral para conocer de las cuestiones litigiosas que se promuevan entre empresarios y trabajadores como consecuencia del contrato de trabajo. A lo largo de su articulado, tanto el Estatuto de los Trabajadores como la Ley de Procedimiento Laboral contemplan el modo en que se extingue la relación laboral por despido declarado improcedente, empleando el artículo 110-1 de la Ley Rituario el término indemnización en relación con la cantidad a abonar al trabajador en caso de no readmisión, y en ningún caso su imposición o ejecución es desvinculada de la jurisdicción laboral, [... ]. En el ámbito de las relaciones estatutarias es el artículo 45 del antiguo texto refundido aprobado por el Decreto 2065/ 1974, de 30 de mayo, vigente de modo paralelo al actual Texto Refundido aprobado por el Real Decreto-Ley 1/ 1994, de 20 de junio, en virtud de su Disposición Derogatoria, el que establece que la relación entre las Entidades Gestoras y en su caso, Servicios de la Seguridad Social y el personal a su servicio se regulará por lo previsto en los Estatutos de Personal aprobados por el Ministerio de Trabajo o por el Estatuto General aprobado por el propio Ministerio, y en el apartado segundo, que la jurisdicción del trabajo será la competente para conocer las cuestiones contenciosas que se susciten entre las Entidades Gestoras y su personal, norma que fue derogada en cuanto al personal funcionario [...], pero no en cuanto al personal estatutario [ ... ]. la supervivencia del artículo 45 del Texto Refundido aprobado pro el Decreto 2065/ 1974, de 30 de mayo, hace que deba tenerse en cuenta el artículo 3-a) de la Ley 29/ 1998 de 13 de julio que niega la competencia de la jurisdicción contencioso-administrativa para conocer de las cuestiones expresamente atribuidas a los órdenes jurisdiccionales civil penal y social, aunque estén relacionados con la actividad de la Administración Pública, con la salvedad que impone la Disposición Adicional

40 La composición de la Sala Especial de Conflictos es la siguiente: Presidente: Excmo. Sr. D. Francisco José H ernando Santiago. Magistrados: Exmos Sres D. Segundo Menéndez Pérez y Dạ María Milagros Calvo I barlucea (Ponente). 
Duodécima de la Ley 4/ 1999, de 13 de enero, al establecer que la responsabilidad de las entidades, servicios u organismos del sistema nacional de la salud y de los centros sanitarios concertados con ellos, por los daños y perjuicios causados por o con ocasión de la asistencia sanitaria y las correspondientes reclamaciones seguirán la tramitación prevista en esta Ley, correspondiendo su revisión jurisdiccional en el orden contencioso-administrativo, en todo caso. De esta forma se cierra el círculo de atracción y exclusión de competencias, evidenciándose, en lo que concierne a la jurisdicción laboral qué indemnizaciones se desplazan de su ámbito al del contencioso-administrativo y cómo se mantiene en el seno de cada una las responsabilidades que derivan de la falta de cumplimiento de obligaciones en relación a su respectivo personal, el funcionario de Administración Pública y el laboral y estatutario que también presta servicios para la misma, tanto si la sanción para la Administración Pública incumplidora se traduce en la exacta ejecución de las obligaciones, proporcionar el descanso, readmitir en el despido, como otorgar una compensación económica cuando tal posibilidad se declare».

En virtud de todo lo expuesto declara la competencia del orden jurisdiccional social para conocer de la cuestión debatida.

\section{FINAL}

Las conclusiones que se pueden extraer se resumen en manifestar el acierto de la magistrada del Juzgado Contencioso-Administrativo N 7 de Madrid, que a su vez fue refrendado por la Sala Especial de Conflictos de Competencia del Tribunal Supremo. Además, y a pesar del debate suscitado, no se modifica el ámbito competencial de los órganos jurisdiccionales en relación con el personal estatutario con lo cual se perpetua esa dualidad jurisdiccional contraria a la naturaleza del personal afectado y a la lógica. Sin embargo, no me cabe duda, que esta cuestión será abordada a través de un proyecto específico sobre la materia, tal y como acertadamente puso de manifiesto el Consejo General del Poder Judicial. 